\title{
Methane production by three widespread marine phytoplankton species: release rates, precursor compounds, and potential relevance for the environment
}

\author{
Thomas Klintzsch $^{1}$, Gerald Langer ${ }^{2}$, Gernot Nehrke ${ }^{3}$, Anna Wieland ${ }^{1}$, Katharina Lenhart ${ }^{1,4}$, and Frank Keppler ${ }^{1,5}$ \\ ${ }^{1}$ Institute of Earth Sciences, University Heidelberg, Im Neuenheimer Feld 234-236, 69120 Heidelberg, Germany \\ ${ }^{2}$ The Marine Biological Association of the United Kingdom, The Laboratory, Citadel Hill, \\ Plymouth, Devon, PL1 2PB, UK \\ ${ }^{3}$ Marine Biogeosciences, Alfred Wegener Institut - Helmholtz-Zentrum für Polar- und \\ Meeresforschung, Bremerhaven, Germany \\ ${ }^{4}$ University of Applied Sciences, Berlinstr. 109, 55411 Bingen, Germany \\ ${ }^{5}$ Heidelberg Center for the Environment HCE, Heidelberg University, 69120 Heidelberg, Germany
}

Correspondence: Thomas Klintzsch (thomas.klintzsch@geow.uni-heidelberg.de) and Frank Keppler (frank.keppler@geow.uni-heidelberg.de)

Received: 21 June 2019 - Discussion started: 1 July 2019

Revised: 28 September 2019 - Accepted: 30 September 2019 - Published: 28 October 2019

\begin{abstract}
Methane $\left(\mathrm{CH}_{4}\right)$ production within the oceanic mixed layer is a widespread phenomenon, but the underlying mechanisms are still under debate. Marine algae might contribute to the observed $\mathrm{CH}_{4}$ oversaturation in oxic waters, but so far direct evidence for $\mathrm{CH}_{4}$ production by marine algae has only been provided for the coccolithophore Emiliania huxleyi.

In the present study we investigated, next to E. huxleyi, other widespread haptophytes, i.e., Phaeocystis globosa and Chrysochromulina sp. We performed $\mathrm{CH}_{4}$ production and stable carbon isotope measurements and provide unambiguous evidence that all three investigated marine algae are involved in the production of $\mathrm{CH}_{4}$ under oxic conditions. Rates ranged from $1.9 \pm 0.6$ to $3.1 \pm 0.4 \mu \mathrm{g}$ of $\mathrm{CH}_{4}$ per gram of POC (particulate organic carbon) per day, with Chrysochromulina sp. and E. huxleyi showing the lowest and highest rates, respectively. Cellular $\mathrm{CH}_{4}$ production rates ranged from $16.8 \pm 6.5$ (P. globosa) to $62.3 \pm 6.4 \mathrm{ag} \mathrm{CH}_{4}$ cell ${ }^{-1} \mathrm{~d}^{-1}$ (E. huxleyi; ag $=10^{-18} \mathrm{~g}$ ). In cultures that were treated with ${ }^{13} \mathrm{C}$-labeled hydrogen carbonate, $\delta^{13} \mathrm{CH}_{4}$ values increased with incubation time, resulting from the conversion of ${ }^{13} \mathrm{C}-$ hydrogen carbonate to ${ }^{13} \mathrm{CH}_{4}$. The addition of ${ }^{13} \mathrm{C}$-labeled dimethyl sulfide, dimethyl sulfoxide, and methionine sulfoxide - known algal metabolites that are ubiquitous in marine surface layers - resulted in the occurrence of ${ }^{13} \mathrm{C}$-enriched
\end{abstract}

$\mathrm{CH}_{4}$ in cultures of E. huxleyi, clearly indicating that methylated sulfur compounds are also precursors of $\mathrm{CH}_{4}$. By comparing the algal $\mathrm{CH}_{4}$ production rates from our laboratory experiments with results previously reported in two field studies of the Pacific Ocean and the Baltic Sea, we might conclude that algae-mediated $\mathrm{CH}_{4}$ release is contributing to $\mathrm{CH}_{4}$ oversaturation in oxic waters. Therefore, we propose that haptophyte mediated $\mathrm{CH}_{4}$ production could be a common and important process in marine surface waters.

\section{Introduction}

Methane $\left(\mathrm{CH}_{4}\right)$, the second most important anthropogenic greenhouse gas after $\mathrm{CO}_{2}$, is the most abundant reduced organic compound in the atmosphere and plays a central role in atmospheric chemistry (Denman et al., 2007; Kirschke et al., 2013; Lelieveld et al., 1998). The mixing ratio of $\mathrm{CH}_{4}$ in the atmosphere has been increasing dramatically from preindustrial values of about 715 parts per billion by volume (ppbv) to about $1868 \mathrm{ppbv}$ (October 2018, NOAA). The global atmospheric $\mathrm{CH}_{4}$ budget is determined by the total emission (540-568 $\mathrm{Tg} \mathrm{CH}_{4} \mathrm{yr}^{-1}$ ) of various sources from terrestrial and aquatic surface areas that are balanced primarily by 
one major sink (hydroxyl radicals) in the atmosphere. The world's oceans are considered to be a minor source of $\mathrm{CH}_{4}$ to the atmosphere (1\%-3\%, Saunois et al., 2016). However, in recent years the widespread occurrence of in situ $\mathrm{CH}_{4}$ production in the ocean mixed layer has received much attention, since $\mathrm{CH}_{4}$ formation in the oxygenated ocean mixed layer challenges the paradigm that biological methanogenesis is a strictly anaerobic process.

Methane is primarily formed by the degradation of buried organic matter under heat and pressure (thermogenic) inside the Earth's crust or produced by the incomplete combustion of biomass (pyrogenic). However, $\mathrm{CH}_{4}$ resulting from microbial processes, carried out by methanogenic archaea under anoxic conditions in soils and sediments or the digestion system of ruminants, is categorized as biogenic or microbial (Kirschke et al., 2013). In contrast to these well-known sources, recent studies have confirmed direct $\mathrm{CH}_{4}$ release from eukaryotes, including plants, animals, fungi, lichens, and the marine alga Emiliania huxleyi even in the absence of methanogenic archaea and in the presence of oxygen or other oxidants (Keppler et al., 2006; Ghyczy et al., 2008; Lenhart et al., 2012, 2015b, 2016). A very recent study also confirmed Cyanobacteria as $\mathrm{CH}_{4}$ producers, suggesting that $\mathrm{CH}_{4}$ production occurs in all three domains of life (Bizic-Ionescu et al., 2018a). These novel sources, from the domains Eucarya and Bacteria, might be classified as biotic non-archaeal $\mathrm{CH}_{4}$ (Boros and Keppler, 2018).

In situ $\mathrm{CH}_{4}$ production in oxygenated surface waters in the marine environment was first reported by Scranton and Farrington (1977) and Scranton and Brewer (1977) and some decades later also for lakes (Grossart et al., 2011). Significant quantities of $\mathrm{CH}_{4}$, produced in upper oxic waters near the air-water interface, might overcome oxidation and thus significantly contribute to $\mathrm{CH}_{4}$ fluxes from aquatic environments to the atmosphere (Bogard et al., 2014). It turned out that in situ $\mathrm{CH}_{4}$ production in the upper oxic waters is a common feature of both oceans and lakes (Forster et al., 2009; Reeburgh, 2007; Tang et al., 2014; Donis et al., 2017; BižićIonescu et al., 2018b; Bange et al., 1994). These results have stimulated the scientific community to study in more detail the phenomenon of $\mathrm{CH}_{4}$ occurrence in oxygenated surface waters. In this context, emissions from Cyanobacteria or algae might help to explain the phenomenon of dissolved $\mathrm{CH}_{4}$ oversaturation. In addition, it has been suggested that $\mathrm{CH}_{4}$ might be produced under phosphorus limitation by the bacterial cleavage of methylphosphonate (MPn) in oligotrophic Pacific regions (Karl et al., 2008; Metcalf et al., 2012; Repeta et al., 2016; Valle and Karl, 2014).

In contrast to this apparently non-oxygen-sensitive pathway, many other studies have identified the "traditionally" archaeal methanogenesis in anoxic microenvironments as a $\mathrm{CH}_{4}$ source. Floating particles (Karl and Tilbrook, 1994), as well as the digestive tracts of zooplankton (de Angelis and Lee, 1994; Stawiarski et al., 2019; Schmale et al., 2018) or fishes (Oremland, 1979), have been found as anoxic micro- niches for methanogens. It has been suggested that some methanogens might be active under oxic conditions by being equipped with enzymes to counteract the effects of molecular oxygen during methanogenesis (Angel et al., 2011). Potential substrates for methylotrophic methanogens in such micro-niches are the algae metabolites dimethylsulfoniopropionate (DMSP) and their degradation products dimethyl sulfide (DMS) or dimethyl sulfoxide (DMSO) (Zindler et al., 2013; Damm et al., 2008; Florez-Leiva et al., 2013). Furthermore, DMSP might also be converted to $\mathrm{CH}_{4}$ by nitrogenlimited bacteria (Damm et al., 2010, 2015). However, in coastal waters where DMS and DMSP production is enhanced, $\mathrm{CH}_{4}$ was found to be mainly related to sedimentary sources (Borges et al., 2018).

In contrast to microbial processes, which are considered to be driven by enzymes, $\mathrm{CH}_{4}$ might also be derived by the chemical reaction of chromophoric dissolved organic matter (CDOM) and DMS induced by UV or visible light under both oxic and anoxic conditions (Zhang et al., 2015). A similar photochemical $\mathrm{CH}_{4}$ formation was described earlier for acetone by Bange and Uher (2005), but the production of $\mathrm{CH}_{4}$ from acetone was considered negligible under oxic conditions.

Under highly oxidative conditions nonheme iron-oxo (IV) species catalyze $\mathrm{CH}_{4}$ formation from methyl thioethers and their sulfoxides (Althoff et al., 2014; Benzing et al., 2017). Iron-oxo species are intermediates in a number of biological enzymatic systems (Hohenberger et al., 2012). Thus, marine algae containing elevated concentrations of methyl thiolethers and their sulfoxides such as DMSP, DMSO, methionine (MET), or methionine sulfoxide (MSO) might be biochemical reactors for non-archaeal $\mathrm{CH}_{4}$ production as was already proposed by Lenhart et al. (2016) and Keppler et al. (2009). Marine phytoplankton plays a central role in the global carbon cycle: approximately half of Earth's primary production is carried out by marine phytoplankton (Field et al., 1998). In this context it is important to mention that almost 40 years ago researchers (Scranton and Brewer, 1977; Scranton and Farrington, 1977; Scranton, 1977) already mentioned the possibility of the in situ formation of $\mathrm{CH}_{4}$ by marine algae, since $\mathrm{CH}_{4}$ production was examined in cultures of E. huxleyi and Thalassiosira pseudonana. Furthermore, direct isotopic evidence for $\mathrm{CH}_{4}$ production by marine algae in the absence of methanogenic archaea has only been provided for E. huxleyi (Lenhart et al., 2016). Based on the application of stable carbon isotope techniques, it could be clearly shown that both hydrogen carbonate and a position-specific ${ }^{13} \mathrm{C}$-labeled MET were carbon precursors of the observed $\mathrm{CH}_{4}$ production. However, it remains unclear whether $\mathrm{CH}_{4}$ production also occurs among other marine algae and if there are also other carbon precursors involved in the formation process.

In the present study we investigated, next to the coccolithophore E. huxleyi, two other marine, non-calcifying haptophytes, namely Phaeocystis globosa and Chrysochro- 
mulina sp., for $\mathrm{CH}_{4}$ formation. The investigated species are all bloom-forming and often found as dominant members in marine phytoplankton communities worldwide (Schoemann et al., 2005; Thomsen, 1994; Brown and Yoder, 1994). Furthermore, they are well-known for their high DMSP, DMS, and DMSO productivity (Liss et al., 1994; Keller, 1989; Holligan et al., 1993; Stefels et al., 2007; Matrai and Keller, 1993). We therefore conducted stable isotope experiments using ${ }^{13} \mathrm{C}$-labeled DMS, MSO, and DMSO to identify potential methyl group precursor compounds that eventually lead to $\mathrm{CH}_{4}$ production. Finally, we discuss the laboratory $\mathrm{CH}_{4}$ production rates in relation to their potential significance in marine environments.

\section{Material and methods}

\subsection{Cultures and culture conditions}

Three algal species, E. huxleyi RCC1216 obtained from the Roscoff Culture Collection (http://roscoff-culture-collection. org/, last access: 21 October 2019), P. globosa PLY 575, and Chrysochromulina sp. PLY 307 obtained from the Marine Biological Association of the United Kingdom (https://www. mba.ac.uk/facilities/culture-collection, last access: 21 October 2019), were studied. In order to keep non-axenic algae cultures largely free of bacteria, the cultures were diluted regularly, resulting in quasi-constant exponential algal growth while minimizing bacterial cell density. All incubation experiments were carried out in controlled and sterile laboratory conditions under a $16 / 8 \mathrm{~h}$ light-dark cycle at a light intensity of $350 \mu \mathrm{mol}$ photons $\mathrm{m}^{-2} \mathrm{~s}^{-1}$ and a temperature of $20^{\circ} \mathrm{C}$. All samples were taken at the end of the light cycle. Monoclonal cultures were grown in full-batch mode (Langer et al., 2013) in sterile filtered $(0.2 \mu \mathrm{m} \varnothing$ pore size $)$ natural North Sea seawater (sampled off Helgoland, Germany) enriched in nutrients according to F/2 medium (Guillard and Ryther, 1962). The initial dissolved inorganic carbon (DIC) of the F/2 medium was $2152 \pm 6 \mu \mathrm{mol} \mathrm{L}^{-1}$ (measured by Shimadzu TOC-V CPH). The DIC value falls within the range of typical DIC concentrations of North Sea seawater.

\subsection{Determination of cell densities}

Cell densities were determined from four aliquots of each culture sample using either a Fuschs-Rosenthal or Neubauer counting chamber, depending on cell density.

\subsection{Incubation with ${ }^{13} \mathrm{C}$-labeled hydrogen carbonate}

To investigate $\mathrm{CH}_{4}$ production by algal cultures, borosilicate glass bottles (Schott, Germany) filled with $2.0 \mathrm{~L}$ of $0.2 \mu \mathrm{m}$ filtered F/2 medium and with $0.35 \mathrm{~L}$ headspace volume were used in our investigations of Chrysochromulina sp. and P. globosa. For the investigations of E. huxleyi $0.85 \mathrm{~L}$ medium and $0.4 \mathrm{~L}$ headspace volume were used (Schott, Ger- many). The vials were sealed airtight with lids (GL 45, PP, two-port, Duran Group) equipped with one three-way port for liquid and a second port fitted with a septum for gas sampling. For measurements of the mixing ratio and stable carbon isotope value of $\mathrm{CH}_{4}\left({ }^{13} \mathrm{C}-\mathrm{CH}_{4}\right)$ samples of headspace $(20 \mathrm{~mL})$ were taken from each vial. Afterwards, samples $(2 \mathrm{~mL})$ for determining cell densities were taken. In order to maintain atmospheric pressure within the vial, the surrounding air was allowed to enter via the three-way port and through a sterile filter to avoid biological contamination. The inflow of surrounding air was taken into consideration when $\mathrm{CH}_{4}$ production was calculated. Cultures that were studied during the incubation were inoculated from a pre-culture grown in dilute-batch mode (Langer et al., 2009). To investigate algal-derived $\mathrm{CH}_{4}$ formation six vials were inoculated with algae and another six vials contained medium only. In addition, three vials of each group were treated with ${ }^{13} \mathrm{C}$-hydrogen carbonate $\left(\mathrm{H}^{13} \mathrm{CO}_{3}^{-}\right)$to investigate $\mathrm{CH}_{4}$ formation by measuring stable carbon isotope values of $\mathrm{CH}_{4}$. Four different treatments were used: medium either with $\mathrm{H}^{13} \mathrm{CO}_{3}^{-}$(medium $+\mathrm{H}^{13} \mathrm{CO}_{3}^{-}$) or without (medium, data not available) and cultures supplemented either with $\mathrm{H}^{13} \mathrm{CO}_{3}^{-}$(medium + culture $+\mathrm{H}^{13} \mathrm{CO}_{3}^{-}$) or without (medium + culture). The different treatments and the number of replicates for the experiments with Chrysochromulina sp. and P. globosa are provided in Fig. 1. Please note that stable isotope measurements using $\mathrm{H}^{13} \mathrm{CO}_{3}^{-}$were not performed for $E$. huxleyi as evidence for the isotope labeling of $\mathrm{CH}_{4}$ was already provided by Lenhart et al. (2016). To study the $\mathrm{CH}_{4}$ formation of $E$. huxleyi by measuring headspace concentration, three replicates (culture and medium group, $n=3$ ) were used.

The overall incubation time was 9,11 , and $6 \mathrm{~d}$ for Chrysochromulina sp., P. globosa, and E. huxleyi, respectively. Headspace and liquid samples were collected on a daily basis for E. huxleyi and in 2-3d intervals from cultures of Chrysochromulina sp. and $P$. globosa. The incubation time and sampling intervals varied between species because of variations in the growth rate and the cell density in the stationary phase. Cell densities were plotted versus time, and the exponential growth rate $(\mu)$ was calculated from exponential regression using the natural logarithm (Langer et al., 2013). The exponential growth phase (from which $\mu$ was calculated) was defined by the cell densities which corresponded to the best fit $\left(r^{2}>0.99\right)$ of the exponential regression. This was done by using the first three (Chrysochromulina sp. and E. huxleyi) or four data points (P. globosa) of the growth curve. For stable carbon isotope experiments $48.7 \mu \mathrm{mol} \mathrm{L}{ }^{-1} \mathrm{NaH}^{13} \mathrm{CO}_{3}$ in final concentration was added to the $\mathrm{F} / 2$ medium. The added amount of $\mathrm{NaH}^{13} \mathrm{CO}_{3}$ corresponds to $2 \%$ of the DIC of the North Sea seawater $\left(2152 \pm 6 \mu \mathrm{mol} \mathrm{L}^{-1}\right)$, resulting in a theoretically calculated $\delta^{13} \mathrm{C}$ value of DIC of $+2014 \pm 331 \%$. To determine the $\delta^{13} \mathrm{C}-\mathrm{CH}_{4}$ values of the source, the Keeling plot method was applied (Keeling, 1958). For a detailed discussion of the 


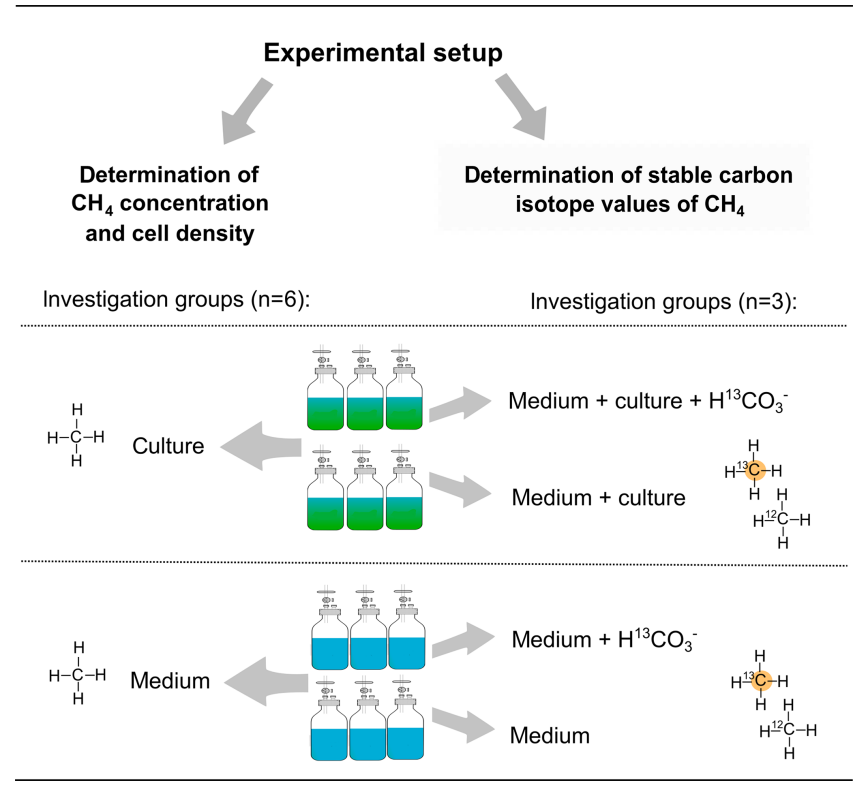

Figure 1. Experimental setup for measuring $\mathrm{CH}_{4}$ formation by Chrysochromulina sp. and P. globosa. Methane formation was investigated by concentration measurements within six vials containing either algae or medium only (left column). For stable isotope measurements of $\mathrm{CH}_{4},{ }^{13} \mathrm{C}$-labeled hydrogen carbonate $\left(\mathrm{H}^{13} \mathrm{CO}_{3}^{-}\right)$ was added to three vials of both groups (right column).

Keeling plot method for determination of the isotope ratio of $\mathrm{CH}_{4}$ in environmental applications, please refer to Keppler et al. (2016). Oxygen concentration was monitored daily (using inline oxygen sensor probes; PreSens, Regensburg) at the end of the light cycle (Fig. S1 in the Supplement).

\subsection{Determination of $\mathrm{CH}_{4}$ production rates}

Since the experiment in the Sect. 2.3 was not designed to obtain POC quotas (POC: particulate organic carbon), we conducted an additional experiment. To best compare the $\mathrm{CH}_{4}$ formation rates of the three algae species it is necessary to obtain exponential growth to ensure constant growth rates and constant (at a given time of day) cellular POC quotas over the course of the experiment. Exponential growth is a prerequisite for calculating production on the basis of growth rate and quota (here $\mathrm{CH}_{4}$ quota). The point is a general, technical one and is not confined to $\mathrm{CH}_{4}$ production. The studies by Langer et al. $(2012,2013)$ discuss this point in the context of batch culture experiments. Briefly, production on this account is the product of growth rate and quota (e.g., $\mathrm{CH}_{4}$, calcite, organic carbon). Production here is an integrated value, typically over many cell divisions. For this calculation of production to be meaningful a constant growth rate is required. The exponential growth phase fulfills this criterion, whereas the transition phase and the stationary phase do not. Therefore, production cannot be calculated meaningfully in the non-exponential phases. The problem can, however, be minimized by using small increments ( $1 \mathrm{~d})$ because growth rate can be regarded as quasi-constant (see also Lenhart et al., 2016). The $\mathrm{CH}_{4}$ production rates can be calculated by multiplying the growth rate $\mu$ with the corresponding cellular or POC- $\mathrm{CH}_{4}$ quota that was measured at the end of the experiment. For this additional experiment the cultures were grown in $160 \mathrm{~mL}$ crimped serum bottles filled with $140 \mathrm{~mL}$ medium and $20 \mathrm{~mL}$ headspace $(n=4)$. Oxygen concentration was monitored (using inline oxygen sensor probes; PreSens, Regensburg) at the end of each light and dark cycle (Fig. S2). The growth rate $(\mu)$ was calculated from cell densities of the beginning and end of the experiment according to Eq. (1):

$\mu=\frac{\operatorname{Ln}\left(N_{1}\right)-\operatorname{Ln}\left(N_{0}\right)}{\left(t_{1}-t_{0}\right)}$,

where $N_{0}$ and $N_{1}$ are the cell densities at the beginning $\left(t_{0}\right)$ and end of the experiment $\left(t_{1}\right)$. The daily cellular $\mathrm{CH}_{4}$ production rates $\left(\mathrm{CH}_{4} \mathrm{P}_{\text {cell }}\right.$, ag $\mathrm{CH}_{4}$ cell ${ }^{-1} \mathrm{~d}^{-1}$, ag $\left.=10^{-18} \mathrm{~g}\right)$ were calculated according to Eq. (2):

$\mathrm{CH}_{4} \mathrm{P}_{\text {cell }}=\mu \times \frac{m\left(\mathrm{CH}_{4}\right)}{\text { cell }}$,

where $m\left(\mathrm{CH}_{4}\right)$ is the amount of $\mathrm{CH}_{4}$ that was produced at the end of the experiment.

To calculate $\mathrm{POC}$-based $\mathrm{CH}_{4}$ production rates the cellular organic carbon content $\left(\mathrm{POC}_{\text {cell }}\right)$ was derived from cell volume ( $\left.V_{\text {cell }}\right)$ by using the Eq. (3) according to Menden-Deuer and Lessard (2000):

$\mathrm{POC}_{\text {cell }}=0.216 \times V_{\text {cell }}^{0.939}$.

The cell volume was determined by measuring the cell diameter in light micrographs using the program Image J (Schindelin et al., 2012). According to Olenina (2006) a ball shape can be assumed for calculating the cell volume for the three species investigated here. The daily cellular $\mathrm{CH}_{4}$ production rates $\left(\mathrm{CH}_{4} \mathrm{P}_{\mathrm{POC}}, \mu \mathrm{g} \mathrm{CH} \mathrm{CH}_{4} \mathrm{~g}^{-1} \mathrm{POC} \mathrm{d}^{-1}\right)$ were calculated from growth rate and $\mathrm{CH}_{4}-\mathrm{POC}$ quotas at the end of the experiment according to Eq. (4).

$\mathrm{CH}_{4} \mathrm{P}_{\mathrm{POC}}=\mu \times \frac{m\left(\mathrm{CH}_{4}\right)}{\mathrm{POC}}$

The $\mathrm{CH}_{4}$ production potential $\left(\mathrm{CH}_{4}-\mathrm{PP}\right)$ was used to translate differences in cellular production rates to the community level. According to Gafar et al. (2018), the $\mathrm{CH}_{4}-\mathrm{PP}$ can be calculated for different periods of growth by calculating a cellular standing stock for each time period from a known starting cell density $\left(N_{0}\right)$ (whereby constant exponential growth is assumed). The corresponding amount of produced $\mathrm{CH}_{4}\left(\mathrm{CH}_{4} \mathrm{PP}\right)$ for each period of growth and standing stock is the product of the cellular standing stock and $\mathrm{CH}_{4}$ quota (Eq. 5).

$\mathrm{CH}_{4} \mathrm{PP}=N_{0} \times e^{\mu \times t} \times \frac{m\left(\mathrm{CH}_{4}\right)}{\text { cell }}$ 
In the present study the $\mathrm{CH}_{4}-\mathrm{PP}$ was calculated for a standing stock that is obtained after $7 \mathrm{~d}$ of growth starting with a single cell.

\subsection{Incubation with ${ }^{13} \mathrm{C}$ labeled DMS, DMSO, and MSO}

The sulfur-bonded methyl group(s) in DMS, DMSO, and MSO were investigated as precursors for algal-derived $\mathrm{CH}_{4}$ in an incubation experiment with $E$. huxleyi. For all tested compounds only the $\mathrm{C}$ atom of the sulfur-bonded methyl group(s) was labeled with ${ }^{13} \mathrm{C}\left(\mathrm{R}-\mathrm{S}-{ }^{13} \mathrm{CH}_{3}, 99 \%\right)$. A final concentration of $10 \mu \mathrm{M}$ was used for each compound. The different treatments to investigate potential $\mathrm{CH}_{4}$ formation by ${ }^{13} \mathrm{C}_{2}$-DMS, ${ }^{13} \mathrm{C}_{2}$-DMSO, ${ }^{13} \mathrm{C}-\mathrm{MSO}$ are provided in Fig. 2. Three independent replicates and repeated measurements over time were used. Headspace and vial size were analogous to the experiment described in Sect. 2.3 for E. huxleyi. Samples were taken daily during an overall incubation time of $6 \mathrm{~d}$.

\subsection{Determination of $\mathrm{CH}_{4}$ mass}

A $5 \mathrm{~mL}$ gas sample was collected from the headspace of the vials using a gastight Hamilton gas syringe. The sample was analyzed by a gas chromatographer (GC-14B, Shimadzu, Japan; column: $2 \mathrm{~m}, \varnothing=3.175 \mathrm{~mm}$ inner diameter, high-grade steel tube packed with molecular sieve 5A 60/80 mesh from Supelco) equipped with a flame ionization detector (FID). Quantification of $\mathrm{CH}_{4}$ was carried out by comparison of the integrals of the peaks eluting at the same retention time as that of the $\mathrm{CH}_{4}$ authentic standard using two reference standards containing 9837 and 2192 ppbv. Mixing ratios were corrected for headspace pressure, which was monitored using a pressure-measuring device (GMSD 1, 3 BA, Greisinger). The $\mathrm{CH}_{4}$ mass $\left(m_{\mathrm{CH}_{4}}\right)$ was determined by its mixing ratio $\left(x_{\mathrm{CH}_{4}}\right)$ and the ideal gas law (Eq. 6):

$m_{\mathrm{CH}_{4}}=M_{\mathrm{CH}_{4}} \times x_{\mathrm{CH}_{4}} \frac{p \times V}{R \times T}$,

where $M_{\mathrm{CH}_{4}}$ is molar mass, $p$ is pressure, $T$ is temperature, $R$ is the ideal gas constant, and $V$ is volume.

The dissolved $\mathrm{CH}_{4}$ concentration was calculated by using the equation of Wiesenburg and Guinasso (1979).

\subsection{GC-C-IRMS measurements}

Stable carbon isotope values of the $\mathrm{CH}_{4}$ of headspace samples were analyzed by gas chromatography-stable isotope ratio mass spectrometry (GC-C-IRMS; Deltaplus XL, Thermo Finnigan, Bremen, Germany). All $\delta^{13} \mathrm{C}-\mathrm{CH}_{4}$ values were corrected using two $\mathrm{CH}_{4}$ working standards (Isometric Instruments, Victoria, Canada) with values of $-23.9 \pm 0.2 \%$ o and $-54.5 \pm 0.2 \%$. The results were normalized by twoscale anchor calibration according to Paul et al. (2007). The average standard deviation of the analytical measurements

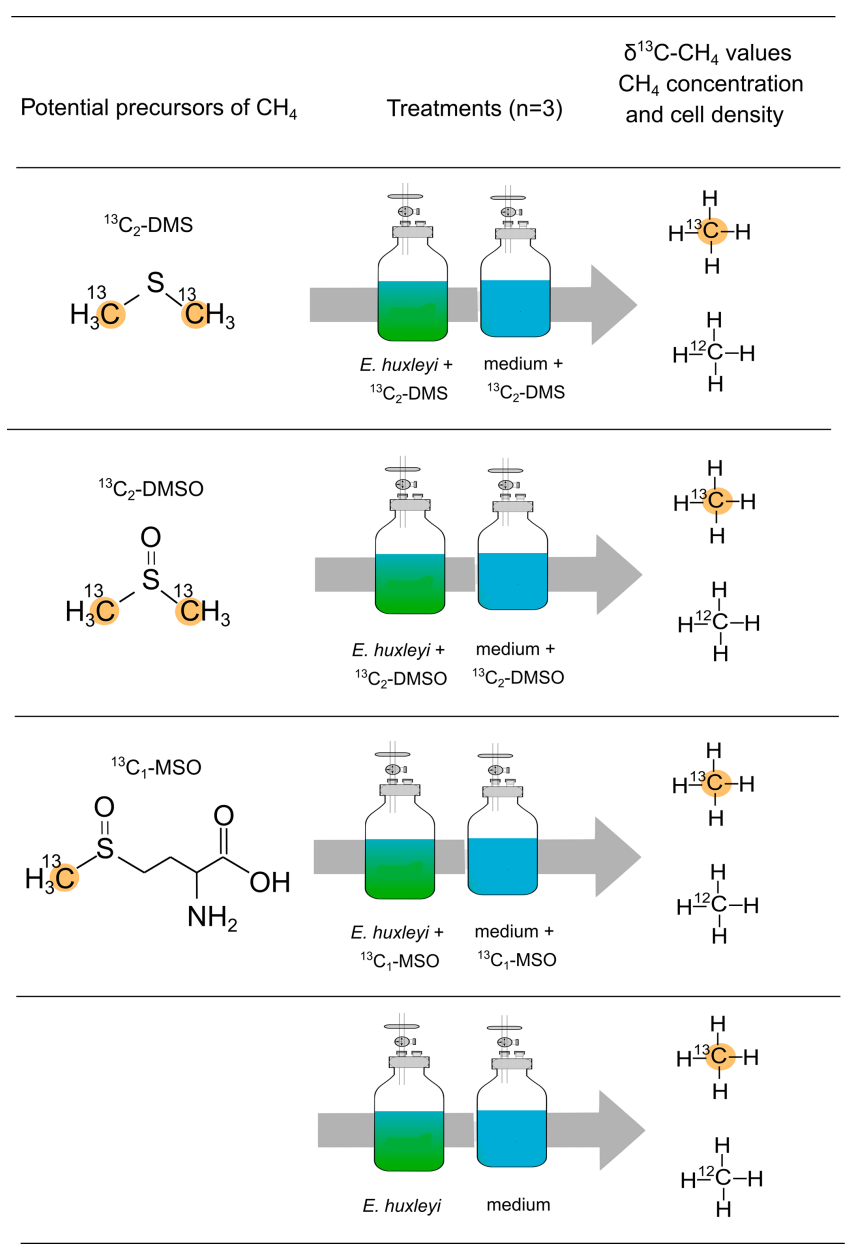

Figure 2. Experimental setup to investigate potential precursor compounds of $\mathrm{CH}_{4}$. Dimethyl sulfide $\left({ }^{13} \mathrm{C}_{2}\right.$-DMS), dimethyl sulfoxide ( ${ }^{13} \mathrm{C}_{2}$-DMSO), and methionine sulfoxide $\left({ }^{13} \mathrm{C}-\mathrm{MSO}\right)$ were added to the vials containing either a culture of $E$. huxleyi or medium only. For all tested compounds only the carbon atom of the sulfur-bonded methyl group(s) was labeled with ${ }^{13} \mathrm{C}$.

was in the range of $0.1 \%$ o to $0.3 \%$ (based on three repeated measurements of $\mathrm{CH}_{4}$ working standards). All $\delta^{13} \mathrm{C}-\mathrm{CH}_{4}$ values are expressed in the conventional $\delta$ notation, in per mille (\%o) vs. Vienna Pee Dee Belemnite (VPDB), using Eq. (7).

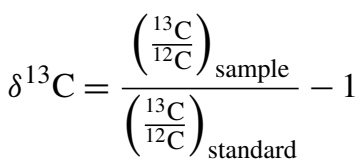

For a detailed description of the $\delta^{13} \mathrm{C}-\mathrm{CH}_{4}$ measurements by GC-IRMS and technical details of the pre-concentration system, we refer the reader to previous studies by Comba et al. (2018) and Laukenmann et al. (2010). 


\subsection{Statistics}

To test for significant differences in cell density, $\mathrm{CH}_{4}$ formation, and $\mathrm{CH}_{4}$ content between the treatments, two-way analysis of variance (ANOVA) (considering repeated measurements) and a post hoc test (Fisher least significant difference (LSD) test; alpha $5 \%$ ) were used.

\section{Results}

\subsection{Algal growth and $\mathrm{CH}_{4}$ formation}

To investigate $\mathrm{CH}_{4}$ production by algal cultures, incubations with ${ }^{13} \mathrm{C}$-labeled hydrogen carbon were applied as described in Sect. 2.3. The growth curves during incubation of the three algal species are presented in Fig. 3 (panels a, b, c). The initial cell densities were $26.9 \pm 4.0 \times 10^{3}{\text { cells } \mathrm{mL}^{-1}}^{-1}$ for Chrysochromulina sp., $25.6 \pm 1.2 \times 10^{3}$ cells $\mathrm{mL}^{-1}$ for P. globosa, and $17.5 \pm 2.0 \times 10^{3}$ cells $\mathrm{mL}^{-1}$ for E. huxleyi. The exponential growth rate $\mu$ was highest for $E$. huxleyi $\left(1.71 \pm 0.04 \mathrm{~d}^{-1}\right)$, i.e., 3 or 5 times higher than for P. globosa and Chrysochromulina sp. (with $0.33 \pm 0.08 \mathrm{~d}^{-1}$ and $0.52 \pm 0.07 \mathrm{~d}^{-1}$, respectively). The dotted lines in Fig. 1a, $\mathrm{b}$, and $\mathrm{c}$ mark the time points of exponential growth. Maximum cell densities were lowest for Chrysochromulina sp. with $0.18 \pm 0.01 \times 10^{6}$ cells $\mathrm{mL}^{-1}$, followed by E. huxleyi with $1.70 \pm 0.09 \times 10^{6}$ cells $\mathrm{mL}^{-1}$, and highest for $P$. globosa with $1.77 \pm 0.15 \times 10^{6}$ cells $\mathrm{mL}^{-1}$. Significant $\mathrm{CH}_{4}$ formation was observed in all three cultures over the whole incubation period of 5 to $11 \mathrm{~d}$ (Fig. 3d, e, f), whereas no increase in $\mathrm{CH}_{4}$ over time was observed in the control groups. For all species the increase in headspace $\mathrm{CH}_{4}$ was significant $(p \leq 0.05)$ at second time point of measurement and at all following time points $(p \leq 0.001)$. At the end of the incubation period the amounts of produced $\mathrm{CH}_{4}$ were $34.9 \pm 7.3,99.3 \pm 8.2$, and $45.0 \pm 3.1 \mathrm{ng}$ for Chrysochromulina sp., P. globosa, and E. huxleyi, respectively. A linear correlation was found between the absolute number of cells and the amount of produced $\mathrm{CH}_{4}$ of Chrysochromulina sp., P. globosa, and E. huxleyi (Fig. 3g, h, i).

\subsection{Stable carbon isotope values of $\mathrm{CH}_{4}$ during incubation with ${ }^{13} \mathrm{C}$-hydrogen carbonate}

Stable carbon isotope values of $\mathrm{CH}_{4}\left(\delta^{13} \mathrm{CH}_{4}\right.$ values) for Chrysochromulina sp. and $P$. globosa are presented in Fig. 4a, c. We observed the conversion of ${ }^{13} \mathrm{C}$ carbon (provided by ${ }^{13} \mathrm{C}$-hydrogen carbonate) to ${ }^{13} \mathrm{CH}_{4}$ in cultures of both species, indicated by increasing $\delta^{13} \mathrm{CH}_{4}$ values over time. Stable isotope values increased from initial atmospheric (laboratory air) levels of $-48.7 \pm 0.3 \%$ and $-48.4 \pm 0.10 \%$ o up to $+30.1 \pm 10.2 \%$ o and $+245 \pm 16 \%$ o for Chrysochromulina sp. and P. globosa, respectively, whilst the $\delta^{13} \mathrm{CH}_{4}$ values of the control groups (algae without ${ }^{13} \mathrm{C}-$ hydrogen carbonate or ${ }^{13} \mathrm{C}$-hydrogen carbonate in medium without culture) did not change over time. The increase in $\delta^{13} \mathrm{CH}_{4}$ values in the headspace $\mathrm{CH}_{4}$ depended on the amount of released $\mathrm{CH}_{4}$ that was added to the initial (atmospheric) background level. To calculate the $\delta^{13} \mathrm{CH}_{4}$ values of the $\mathrm{CH}_{4}$ source that raised the $\mathrm{CH}_{4}$ quantity above background level, the Keeling plot method (Keeling, 1958; Pataki et al., 2003) was used (Fig. 4b, d). The calculated $\delta^{13} \mathrm{CH}_{4}$ values of the $\mathrm{CH}_{4}$ source were $+1300 \pm 245 \%$ o (Chrysochromulina sp.) and $+1511 \pm 35 \%$ o (P. globosa) and thus close to the theoretical calculated ${ }^{13} \mathrm{C}$ value of the DIC $\left(2014 \pm 331 \%\right.$ ) resulting from the addition of ${ }^{13} \mathrm{C}$-hydrogen carbonate. Please note that ${ }^{13} \mathrm{C}$-hydrogen carbonate stable isotope labeling experiments with E. huxleyi were already performed by Lenhart et al. (2016) and were not repeated in this study. This is why $\delta^{13} \mathrm{CH}_{4}$ values and the respective Keeling plot of E. huxleyi are not shown in Fig. 4.

\section{3 $\mathrm{CH}_{4}$ production and production potential}

Since the experiment in the section above (isotope measurements) was not designed to obtain POC quotas, we conducted an additional experiment to estimate the $\mathrm{CH}_{4}$ production rates of the three algal species. From an initial cell density of $22.5 \pm 3.1 \times 10^{3}, 80.9 \pm 11.5 \times 10^{3}$, and $29.0 \pm$ $5.5 \times 10^{3}$ cells $\mathrm{mL}^{-1}$ cultures were grown up to $37.0 \pm 9.2 \times$ $10^{3}, 219 \pm 24.1 \times 10^{3}$, and $283 \pm 15.6 \times 10^{3}$ cells $\mathrm{mL}^{-1}$ for Chrysochromulina sp., P. globosa, and E. huxleyi, respectively. These cell densities corresponded to the cell densities of the exponential growth phase obtained from the experiment in Sect. 3.1. The POC-normalized daily $\mathrm{CH}_{4}$ production rate was highest in E. huxleyi, followed by $P$. globosa and Chrysochromulina sp. However, the cellular or POCnormalized daily production rates of the three algal species were of the same order of magnitude (Table 1). We calculated the $\mathrm{CH}_{4}$ production potential $\left(\mathrm{CH}_{4} \mathrm{PP}\right)$, which is the amount of $\mathrm{CH}_{4}$ produced within a week of growth $(\mathrm{Ga}-$ far et al., 2018), to translate the cellular production rates $\left(\mu \times \mathrm{CH}_{4}\right.$ cell $\left.^{-1}\right)$ of each species to the community level. The $\mathrm{CH}_{4}-\mathrm{PP}$ was 2 orders of magnitude higher for E. huxleyi than the other two species. This is a consequence of the higher growth rate of E. huxleyi. We furthermore observed the oxygen concentrations during the light and dark periods to ensure oxic conditions. The measured oxygen concentrations were always saturated or supersaturated relative to equilibration with ambient air (Fig. S2).

\section{4 $\mathrm{CH}_{4}$ formation from ${ }^{13} \mathrm{C}$-labeled methyl thiol ethers}

The three methylated sulfur compounds MSO, DMSO, and DMS were tested for potential $\mathrm{CH}_{4}$ formation in incubation experiments with $E$. huxleyi. The treatments were initiated in parallel from a batch culture by inoculating $17.5 \pm 2.0 \times$ $10^{3}$ cells $\mathrm{mL}^{-1}$, and cultures were grown to final cell densities of $1.77 \pm 0.08 \times 10^{6}$ cells mL $^{-1}$ (Fig. 5a). Cell densi- 

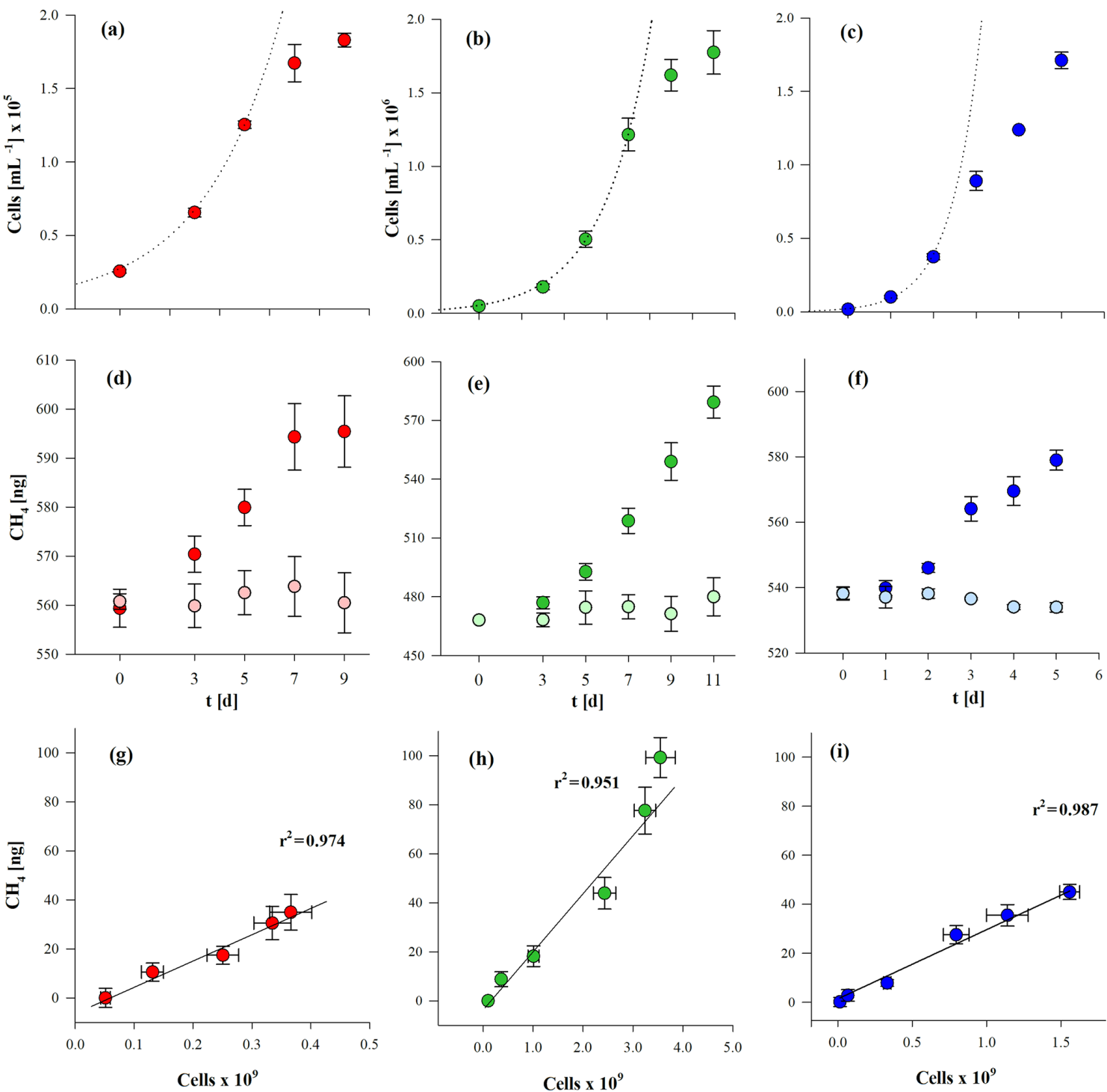

- Chrysochromulina sp.

O Medium

P. globosa

○ Medium
- E. huxleyi

- Medium

Figure 3. Cell growth $(\mathbf{a}, \mathbf{b}, \mathbf{c})$ and $\mathrm{CH}_{4}$ production $(\mathbf{d}, \mathbf{e}, \mathbf{f})$ in the course of time and the correlation between the total number of cells and produced $\mathrm{CH}_{4}(\mathbf{g}, \mathbf{h}, \mathbf{i})$ from three algae species. Chrysochromulina sp. (a, d, $\left.\mathbf{g}\right)$, P. globosa (b, e, h), and E. huxleyi (c, f, i). Please note that the cell numbers of Chrysochromulina sp. are presented in $10^{5}$ and those of $P$. globosa and E. huxleyi are in $10^{6}$. Mean values of six (Chrysochromulina sp., P. globosa) and three (E. huxleyi) replicated culture experiments are shown, and error bars mark the SD.

Table 1. Growth rate, cellular $\mathrm{POC}, \mathrm{CH}_{4}$ production rates, and $\mathrm{CH}_{4}-\mathrm{PP}_{(7 \mathrm{~d})}$ of Chrysochromulina sp. $(n=4), P . g l o b o s a(n=4)$, and $E$. huxleyi $(n=4)$. Values are the mean of four replicated culture experiments with SD.

\begin{tabular}{lrrrrr}
\hline & Growth rate $(\mu)$ & Cellular POC & \multicolumn{2}{c}{$\mathrm{CH}_{4}$ production rate } & $\mathrm{CH}_{4} \mathrm{PP}_{(7 \mathrm{~d})}$ \\
\cline { 3 - 5 } & $\mathrm{d}^{-1}$ & $\mathrm{pg} \mathrm{cell}^{-1}$ & $\mathrm{ag} \mathrm{CH}_{4}$ cell $^{-1} \mathrm{~d}^{-1}$ & $\mu_{\mathrm{g} \mathrm{CH}} \mathrm{g} \mathrm{g}_{4}{ }^{-1} \mathrm{POC} \mathrm{d}^{-1}$ & $\mathrm{fg} \mathrm{CH}_{4}$ \\
\hline Chrysochromulina sp. & $0.21 \pm 0.04$ & $25.4 \pm 4.0$ & $44.5 \pm 13.9$ & $1.9 \pm 0.6$ & $1.0 \pm 0.3$ \\
P. globosa & $0.50 \pm 0.06$ & $7.0 \pm 0.4$ & $16.8 \pm 6.5$ & $2.4 \pm 0.9$ & $1.1 \pm 0.4$ \\
E. huxleyi & $1.09 \pm 0.02$ & $20.1 \pm 0.7$ & $62.3 \pm 6.4$ & $3.1 \pm 0.4$ & $121 \pm 9.0$ \\
\hline
\end{tabular}



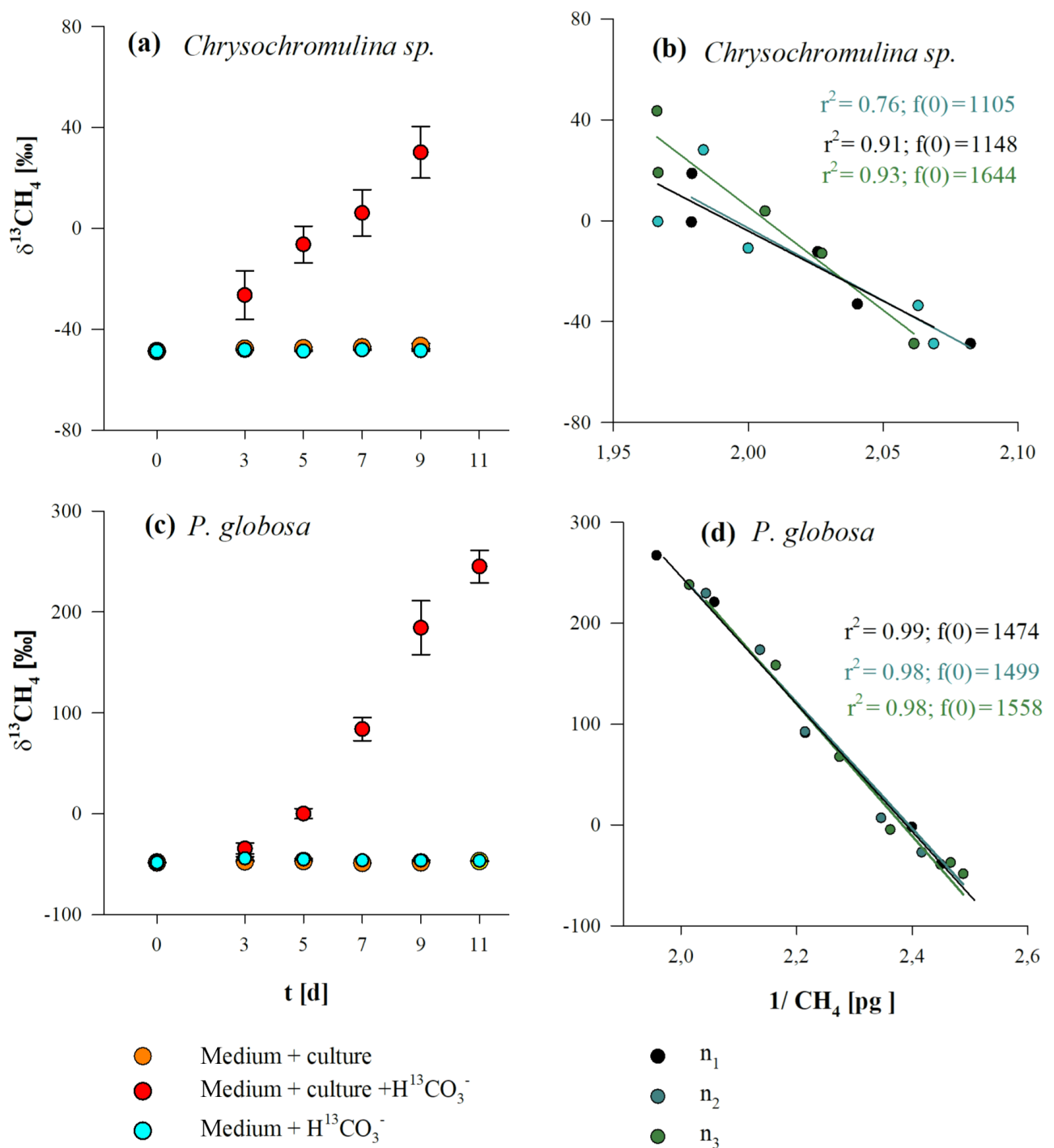

Figure 4. $\delta^{13} \mathrm{CH}_{4}$ values (a, c) and respective Keeling plots (b, d) from Chrysochromulina sp. (a, b) and $P$. globosa (c, d) after the addition of $\mathrm{H}^{13} \mathrm{CO}_{3}^{-}$. Panels (a, c) show the $\delta^{13} \mathrm{CH}_{4}$ values of three investigation groups ("culture $+\mathrm{H}^{13} \mathrm{CO}_{3}^{-}$", "culture", and " $\mathrm{H}^{13} \mathrm{CO}_{3}^{-}$"), whereas each data point presented is the mean value of three replicated culture experiments with error bars showing SD. Panels (b, d) show the Keeling plots for the treatments "culture $+\mathrm{H}^{13} \mathrm{CO}_{3}^{-}$" from each replicated culture experiment $\left(n_{1}, n_{2}, n_{1}\right)$, where $\mathrm{f}(0)$ refers to the ${ }^{13} \mathrm{C}$ value of the $\mathrm{CH}_{4}$ source.

ties and $\mathrm{CH}_{4}$ formation correlated in all treatments, while no difference in cell growth pattern or $\mathrm{CH}_{4}$ formation was observed when isotope-labeled methyl thioether and sulfoxides were added to the culture (Fig. 5a, b, c). Differences between treatments were found in $\delta^{13} \mathrm{CH}_{4}$ values of headspace $\mathrm{CH}_{4}$. The initial $\delta^{13} \mathrm{CH}_{4}$ value of headspace $(-47.9 \pm 0.1 \%$, laboratory air) increased slightly over time in untreated cultures (without isotope treatment) to $-46.8 \pm$ $0.3 \%$ (Fig. 6b). In contrast, experiments in which ${ }^{13} \mathrm{C}_{2}-$ DMS, ${ }^{13} \mathrm{C}_{2}$-DMSO, and ${ }^{13} \mathrm{C}-\mathrm{MSO}$ were applied to cultures of E. huxleyi, $\delta^{13} \mathrm{CH}_{4}$ values increased to $-31.0 \pm 1.1 \%$, $-45.7 \pm 0.1 \%$, and $+18.3 \pm 7.7 \%$, respectively, over a time period of $6 \mathrm{~d}$ (Fig. $6 \mathrm{a}, \mathrm{b}, \mathrm{c}$ ) and differed significantly from control groups $(p<0.05)$. The results unambiguously show that a fraction of the ${ }^{13} \mathrm{C}$-labeled methyl groups of the added substances was converted to ${ }^{13} \mathrm{C}-\mathrm{CH}_{4}$ in cultures of $E$. huxleyi. Much smaller changes in $\delta^{13} \mathrm{CH}_{4}$ values were observed for controls of sterile filtered media to which only ${ }^{13} \mathrm{C}_{2}$-DMS and ${ }^{13} \mathrm{C}-\mathrm{MSO}$ were added $(-42.8 \pm 1.7 \%$ and $-43.9 \pm 0.2 \%$, respectively; Fig. 6a, c; day 6), whereas $\delta^{13} \mathrm{CH}_{4}$ values did not change over time in the seawater controls (no addition of isotopic-labeled compounds) or in the seawater controls treated with ${ }^{13} \mathrm{C}_{2}$-DMSO (Fig. 6b). Based on the initial amount of ${ }^{13} \mathrm{C}$-labeled substance that was added to the cultures and the total amount of ${ }^{13} \mathrm{CH}_{4}$ at the end of the incubation period, $9.5 \pm 0.2 \mathrm{pmol}\left({ }^{13} \mathrm{C}_{2}-\right.$ 
DMS $), 3.0 \pm 3.2 \mathrm{pmol}\left({ }^{13} \mathrm{C}_{2}-\mathrm{DMSO}\right)$, and $30.1 \pm 3.6 \mathrm{pmol}$ $\left({ }^{13} \mathrm{C}-\mathrm{MSO}\right)$ of $8.5 \mu \mathrm{mol}$ were converted to $\mathrm{CH}_{4}$.

\section{Discussion}

Our results of $\mathrm{CH}_{4}$ production and stable carbon isotope measurements provide unambiguous evidence that next to $E$. huxleyi (Lenhart et al., 2016) other widespread marine algal species, namely Chrysochromulina sp. and P. globosa, are involved in the production of $\mathrm{CH}_{4}$ under oxic conditions at rates of $1.9 \pm 0.6$ to $3.1 \pm 0.4 \mu \mathrm{g} \mathrm{CH}_{4} \mathrm{~g}^{-1} \mathrm{POC} \mathrm{d}^{-1}$. The three investigated genera of marine phytoplankton have a worldwide distribution and they are representatives of the most widespread marine haptophytes (Schoemann et al., 2005; Thomsen, 1994; Brown and Yoder, 1994). The results indicate that $\mathrm{CH}_{4}$ production could be a common process across marine haptophytes. We first discuss the stable isotopic evidence of $\mathrm{CH}_{4}$ formation, the role of precursor compounds, and the likely mechanisms involved. Finally, we discuss the laboratory $\mathrm{CH}_{4}$ production rates in relation to their potential significance in marine environments and provide a first rough estimation of how these production rates might contribute to $\mathrm{CH}_{4}$ concentration in oxic surface waters previously reported in open-ocean algal blooms.

In cultures of Chrysochromulina sp. and P. globosa that were treated with ${ }^{13} \mathrm{C}$-labeled hydrogen carbonate, $\delta^{13} \mathrm{CH}_{4}$ values increased with incubation time, clearly resulting from the conversion of ${ }^{13} \mathrm{C}$-hydrogen carbonate to ${ }^{13} \mathrm{CH}_{4}$. These results demonstrate that all three investigated algal species are instrumental in the production of $\mathrm{CH}_{4}$ under oxic conditions (Fig. S1) and that hydrogen carbonate serves as a carbon source for ${ }^{13} \mathrm{CH}_{4}$. Our findings are in agreement with the stable isotope evidence of $\mathrm{CH}_{4}$ production by $E$. huxleyi (Lenhart et al., 2016). However, we do not consider hydrogen carbonate to be the direct carbon precursor of $\mathrm{CH}_{4}$. In a first step hydrogen carbonate and its isotope label are converted to $\mathrm{CO}_{2}$ and subsequently fixed by algal primary production, forming POC. Therefore, we would expect a large fraction of the ${ }^{13} \mathrm{C}$ label of the hydrogen carbonate $(+2014 \pm 331 \%$ ) to be transferred to the POC towards the end of the experiment (when the volume-normalized POC content is highest). The experiments were started by the inoculation of cells from precultures that were grown on DIC with natural ${ }^{13} \mathrm{C} /{ }^{12} \mathrm{C}$ abundance $\left(\delta^{13} \mathrm{C}\right.$ values $\sim 0 \%$ ). This means that during ongoing incubation the $\delta^{13} \mathrm{C}-\mathrm{POC}$ value should get close to $\delta^{13} \mathrm{C}-$ DIC values, resulting from the addition of ${ }^{13} \mathrm{C}$-hydrogen carbonate when cultures grow in the new ${ }^{13} \mathrm{C}$-enriched medium. Consequently, the $\delta^{13} \mathrm{C}-\mathrm{POC}$ values are considered to be somewhat lower than the theoretically calculated $\delta^{13} \mathrm{C}-\mathrm{DIC}$ values $(+2014 \pm 331 \%$ o o the medium. Our assumptions are in line with the $\delta^{13} \mathrm{CH}_{4}$ source signature values (averaged over 9 or $11 \mathrm{~d}$, respectively) obtained via the Keeling plot method, which were $+1300 \pm 245 \%$ and $+1511 \pm 35 \%$ for Chrysochromulina sp. and P. globosa, respectively, and were thus somewhat lower than for the theoretical calculated ${ }^{13} \mathrm{C}$ value of the DIC $(+2014 \pm 331 \%$ o resulting from the addition of ${ }^{13} \mathrm{C}$-hydrogen carbonate. Unfortunately, $\delta^{13} \mathrm{C}$-DIC and $\delta^{13} \mathrm{C}-\mathrm{POC}$ values could not be determined in our set of experiments to allow for more detailed calculations. However, our results clearly indicate that hydrogen carbonate is the principal inorganic carbon precursor of ${ }^{13} \mathrm{CH}_{4}$ produced in algae, but intermediate metabolites are likely to be formed from which $\mathrm{CH}_{4}$ is released, possibly by cleavage of sulfurbonded methyl groups of methyl thioethers and sulfoxides (Althoff et al., 2014; Lenhart et al., 2016; Benzing et al., 2017).

\section{1 $\mathrm{CH}_{4}$ formation from ${ }^{13} \mathrm{C}$-labeled methyl thioethers}

\subsubsection{Methyl thioethers are precursors of $\mathrm{CH}_{4}$}

Methyl thioethers and their sulfoxides are ubiquitous in marine environments as they are often produced by algae at substantial rates. It is also known that these compounds are metabolized in the three investigated algal species (Liss et al., 1994; Keller, 1989). Based on the addition of ${ }^{13} \mathrm{C}_{2}$-DMSO, ${ }^{13} \mathrm{C}_{2}$-DMS, and ${ }^{13} \mathrm{C}-\mathrm{MSO}$, whereby only the sulfur-bonded methyl groups $\left(-\mathrm{S}-\mathrm{CH}_{3}\right)$ were $99 \%$ labeled with ${ }^{13} \mathrm{C}$, it was possible to clearly monitor ${ }^{13} \mathrm{CH}_{4}$ formation by stable carbon isotope measurements in cultures of $E$. huxleyi. The $\delta^{13} \mathrm{CH}_{4}$ values increased over time significantly in ${ }^{13} \mathrm{C}_{2}$-DMS, ${ }^{13} \mathrm{C}_{2}-$ DMSO, and ${ }^{13} \mathrm{C}-\mathrm{MSO}$ treated cultures, above the $\delta^{13} \mathrm{CH}_{4}$ values of the control groups (Fig. $6 \mathrm{a}-\mathrm{c}$ ). The ${ }^{13} \mathrm{C}$ labeling experiment showed that DMS, DMSO, and MSO are potentially important methyl precursors for $\mathrm{CH}_{4}$, but the contribution of these compounds to the overall $\mathrm{CH}_{4}$ production in cultures of E. huxleyi could not be determined in our experiments due to the complexity of the formation of these compounds in the algal cells. This can be illustrated by the following. The contribution of a substance to the total $\mathrm{CH}_{4}$ released is the product of both the added ${ }^{13} \mathrm{C}$-labeled fraction (added to the water sample and uptake by the cells) and the internally formed fraction of these compounds (DMS, DMSO, and MSO), which will roughly show natural ${ }^{13} \mathrm{C}$ abundance. Therefore, the stable isotope value of $\mathrm{CH}_{4}$ will be diluted by the fraction of naturally formed methyl sulfur compounds in the algal cells, and thus the contribution of DMS, DMSO, and MSO to $\mathrm{CH}_{4}$ formation cannot be estimated on the basis of their added amount alone. The ${ }^{13} \mathrm{CH}_{4}$ quantity from the conversion of added ${ }^{13} \mathrm{C}$-labeled substance contributed $0.03 \%\left({ }^{13} \mathrm{C}_{2}-\mathrm{DMSO}\right)$ up to $0.84 \%$ $\left({ }^{13} \mathrm{C}-\mathrm{MSO}\right)$ to the overall released $\mathrm{CH}_{4}$. However, even if the added ${ }^{13} \mathrm{C}$-labeled compounds might only explain $\leq 1 \%$ of $\mathrm{CH}_{4}$ formed by the algae, their overall contribution (including non-labeled sulfur compounds, which we are not able to measure) might provide a much larger fraction of the released $\mathrm{CH}_{4}$. The intracellular DMS concentration can reach $1 \mathrm{mM}$ (Sunda et al., 2002) in cells of E. huxleyi, while the concentration of added ${ }^{13} \mathrm{C}_{2}$-DMS was $0.01 \mathrm{mM}$ in medium 

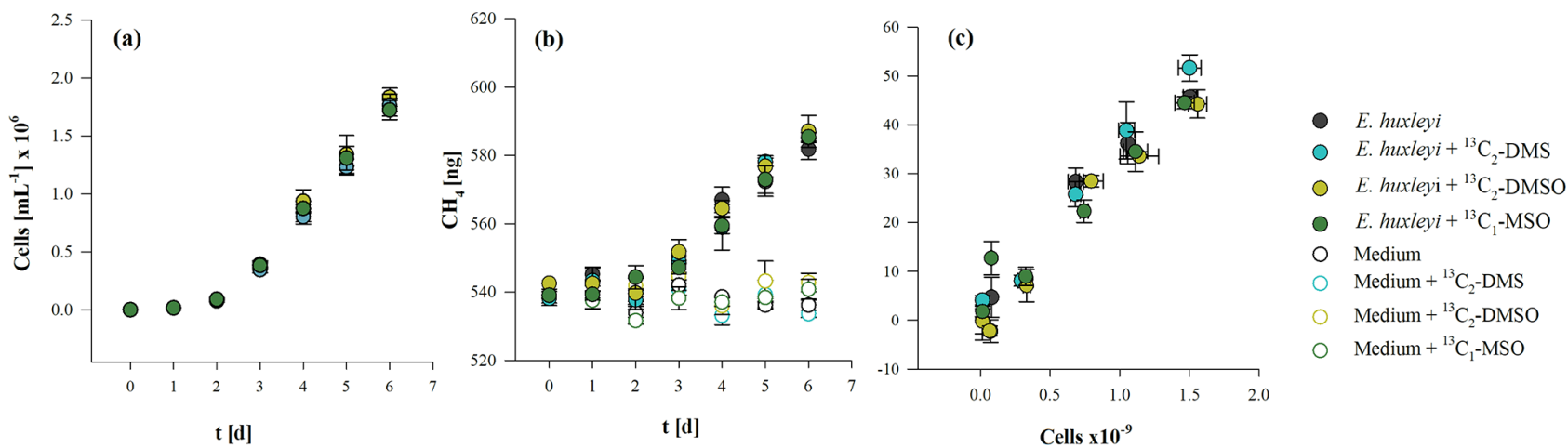

Figure 5. Cell growth (a), $\mathrm{CH}_{4}$ production (b), and the relation between the total number of cells and produced $\mathrm{CH}_{4}(\mathbf{c})$ from $E$. huxleyi treated with ${ }^{13} \mathrm{C}_{2}$-DMS, ${ }^{13} \mathrm{C}_{2}$-DMSO, and ${ }^{13} \mathrm{C}-\mathrm{MSO}$ or without any treatment. Mean values of three replicated culture experiments are shown, and error bars mark the SD.
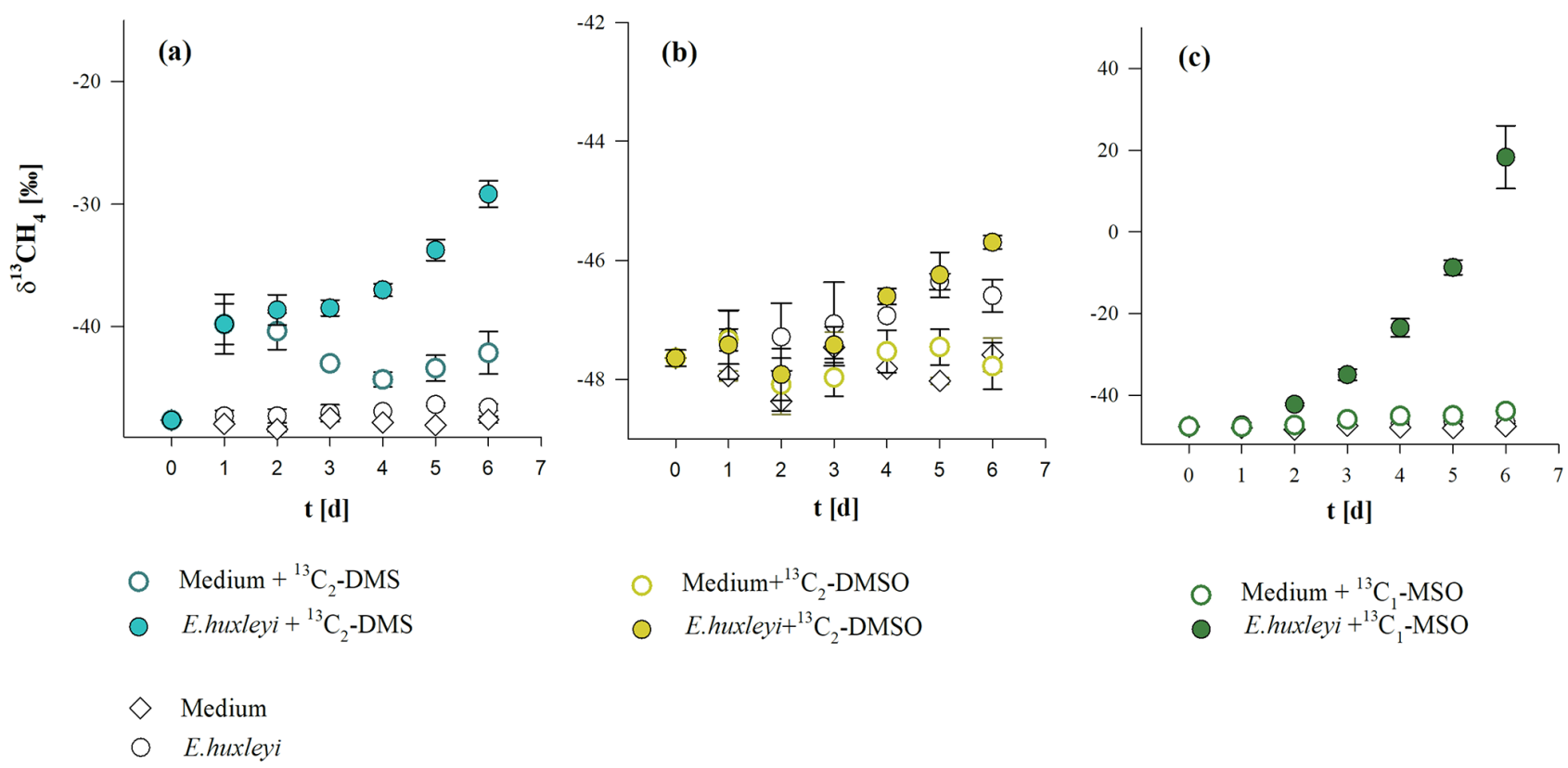

Medium $+{ }^{13} \mathrm{C}_{1}-\mathrm{MSO}$
E.huxleyi $+{ }^{13} \mathrm{C}_{1}$-MSO

Figure 6. $\delta^{13} \mathrm{CH}_{4}$ values of headspace $\mathrm{CH}_{4}$ in cultures of $E$. huxleyi supplemented with (a) ${ }^{13} \mathrm{C}_{2}-\mathrm{DMS}$, (b) ${ }^{13} \mathrm{C}_{2}-\mathrm{DMSO}$, and (c) ${ }^{13} \mathrm{C}-\mathrm{MSO}$. Mean values of three replicated culture experiments are shown, and error bars mark the SD.

(final concentration). If intracellular ${ }^{13} \mathrm{C}_{2}-\mathrm{DMS}$ was in equilibrium with bulk seawater ${ }^{13} \mathrm{C}_{2}-\mathrm{DMS}$ and all $\mathrm{CH}_{4}$ was produced from intracellular DMS, then the contribution of the ${ }^{13} \mathrm{C}$-labeled compound would be about $1 \%$. However, even if the biggest fraction of $\mathrm{CH}_{4}$ in algae cultures was not released by the ${ }^{13} \mathrm{C}$-labeled substances, the significant increase in delta notation in ${ }^{13} \mathrm{C}_{2}-\mathrm{DMS},{ }^{13} \mathrm{C}_{2}$-DMSO, and ${ }^{13} \mathrm{C}-\mathrm{MSO}$ treated cultures above the $\delta^{13} \mathrm{CH}_{4}$ values of the control groups demonstrates that ${ }^{13} \mathrm{C}$-labeled precursor substances were converted to $\mathrm{CH}_{4}$ by algal cultures (Fig. $6 \mathrm{a}-\mathrm{c}$ ). This is also indicated when the absolute conversion quantities of ${ }^{13} \mathrm{C}$-labeled substance in algal cultures are considered: these were ca. $9\left({ }^{13} \mathrm{C}_{2}\right.$-DMS $), 3\left({ }^{13} \mathrm{C}_{2}-\mathrm{DMSO}\right)$, and $30\left({ }^{13} \mathrm{C}-\mathrm{MSO}\right)$ times higher than in seawater control groups.
Hence, the stable isotope labeling approach should be considered as a proof of concept that methyl groups of all tested substance serve as precursor compounds of $\mathrm{CH}_{4}$. These isotope labeling results are also in good agreement with recent results from laboratory experiments in which ${ }^{13} \mathrm{C}-\mathrm{MET}$ was added to cultures of E. huxleyi (Lenhart et al., 2016).

In addition, we also found an indication for a purely chemical $\mathrm{CH}_{4}$ formation pathway from control samples using sterile seawater and the addition of either ${ }^{13} \mathrm{C}_{2}$-DMS or ${ }^{13} \mathrm{C}-$ MSO. The ${ }^{13} \mathrm{C}_{2}$-DMS-spiked seawater group and the ${ }^{13} \mathrm{C}_{2}-$ DMS-spiked algae group are very close to each other up to day 2 (see Figs. 5a and 6a). For this time period, it can be assumed that the chemical conversion has taken place in both samples to the same extent, since the samples are 
relatively similar because the algal cell density is only $5 \%$ (day 2) of the final cell density. However, the following days (day 3 to day 6), when algal cell density increased drastically, the $\delta^{13} \mathrm{CH}_{4}$ values of the algae cultures also increased significantly compared with $\delta^{13} \mathrm{CH}_{4}$ values of the seawater. This clearly indicates that the conversion of ${ }^{13} \mathrm{C}_{2}-\mathrm{DMS}$ to $\mathrm{CH}_{4}$ increases with increasing cell counts. However, the relatively slight increase in $\delta^{13} \mathrm{CH}_{4}$ values in the control samples (Fig. 6a, c) indicates that this is only a minor pathway. The $\mathrm{CH}_{4}$ conversion from ${ }^{13} \mathrm{C}$-DMS and ${ }^{13} \mathrm{C}-\mathrm{MSO}$ in seawater was approximately 3- and 30-fold lower than in the corresponding treatments with algae and only becomes obvious when applying very sensitive stable isotope labeling experiments. A similar observation was already made by Lenhart et al. (2016) when applying ${ }^{13} \mathrm{C}-\mathrm{MET}$ in seawater. However, this observation might be in agreement with previously findings by Zhang et al. (2015), who described a photochemically and CDOM-related conversion of DMS to $\mathrm{CH}_{4}$ in oxygenated natural seawater.

\subsubsection{Potential mechanism of $\mathrm{CH}_{4}$ formation from thioethers}

The $\mathrm{CH}_{4}$ formation from thioethers (MET, DMS) and their corresponding sulfoxides (MSO, DMSO) might be catalyzed by nonheme iron-oxo (IV), thus forming methyl radicals $\left(\cdot \mathrm{CH}_{3}\right)$ from homolytically broken sulfur methyl bounds $\left(\mathrm{R}-\mathrm{CH}_{3}\right)$, leading to $\mathrm{CH}_{4}$ under oxidative conditions (Althoff et al., 2014; Benzing et al., 2017). The tested compounds are found in high cellular concentrations in E. huxleyi, Chrysochromulina sp., and P. globosa, and nonheme iron-oxo (IV) has been identified as an active intermediate in the catalytic cycles of a number of biological enzymatic systems (Hohenberger et al., 2012). Therefore, the postulated reaction might be a likely pathway for $\mathrm{CH}_{4}$ production in investigated algal species. Furthermore, DMS and DMSO were described to be part of an antioxidant system as these compounds can readily scavenge hydroxyl radicals in cells of $E$. huxleyi (Sunda et al., 2002). Furthermore, $\mathrm{CH}_{4}$ is released via a methyl radical that is subtracted from DMSO when hydroxyl radicals are being scavenged - and accordingly DMS after its sulfoxidation (Herscu-Kluska et al., 2008). Since MET and MSO have similar functional groups to DMS and DMSO, respectively, it was proposed that the reaction described above is taking place analogously for these compounds (Bruhn et al., 2012; Lenhart et al., 2015a). Consequently, the $\mathrm{CH}_{4}$ formation in investigated algal species might be a response of oxidative stress that forms hydroxyl radicals or other reactive oxygen species (ROS), which in turn might react with the applied methylated sulfur compounds, generating methyl radicals and eventually $\mathrm{CH}_{4}$.

The algal metabolites DMSP, DMS, and DMSO are ubiquitous in marine surface layers and nanomolar concentrations were found in blooms of Chrysochromulina sp., P. globosa, and E. huxleyi. Several field studies showed that these com- pounds are linked to $\mathrm{CH}_{4}$ formation in seawater (Zindler et al., 2013; Damm et al., 2008; Florez-Leiva et al., 2013). Various authors have proposed that DMSP and its degradation products DMSO and DMS are used by methylotrophic methanogenic archaea, inhabiting anoxic microsites, as substrates for methanogenesis. In addition it was reported that, if nitrogen is limited but phosphorus is replete, marine bacteria might also use DMSP as a carbon source, thereby releasing $\mathrm{CH}_{4}$ (Damm et al., 2010). One scenario which we cannot rule out would be the production of $\mathrm{CH}_{4}$ precursors by algae and the usage of these precursors by bacteria to produce $\mathrm{CH}_{4}$. While we think that this is less likely than $\mathrm{CH}_{4}$ production by algae alone, it would, if true, show that bacteria need algae-produced precursors to produce $\mathrm{CH}_{4}$. The latter scenario would be relevant in the field because algae coexist with bacteria in the oceans. Therefore, bacteria might be involved in the $\mathrm{CH}_{4}$ production process in our cultures, but even if they were, they would still depend on algal growth. For further discussion of a potential contribution of heterotrophs and/or methanogenic archaea, see the Supplement (S3). The correlations we describe in the Supplement clearly show that $\mathrm{CH}_{4}$ production depends on algal growth. It is therefore highly unlikely that bacteria are solely responsible for $\mathrm{CH}_{4}$ production in our cultures.

\subsection{POC-normalized production}

For all three algal species significant correlations between $\mathrm{CH}_{4}$ mass and cell density were found $\left(r^{2}>0.95\right.$ for all species; Fig. 3g, h, i), suggesting that $\mathrm{CH}_{4}$ formation occurred over the entire growth curve. However, since $\mathrm{CH}_{4}$ production can only be determined in the exponential phase (Langer et al., 2013) we additionally ran dilute batch cultures to determine $\mathrm{CH}_{4}$ production. All three species displayed similar $\mathrm{CH}_{4}$ production ranging from $1.9 \pm 0.6$ to $3.1 \pm 0.4 \mu \mathrm{g} \mathrm{CH}_{4} \mathrm{~g}^{-1} \mathrm{POC} \mathrm{d}^{-1}$, with Chrysochromulina sp. and $E$. huxleyi showing the lowest and highest rates, respectively. The $\mathrm{CH}_{4}$ production for $E$. huxleyi was found to be 2-fold higher than rates reported for the same strain and comparable culture conditions by Lenhart et al. (2016) $\left(0.7 \mu \mathrm{C} \mathrm{CH}_{4} \mathrm{~g}^{-1} \mathrm{POC} \mathrm{d}^{-1}\right)$. The lower production reported by Lenhart et al. (2016) may be explained by the fact that $\mathrm{CH}_{4}$ production was not obtained from exponentially growing cultures. We also compared the cellular $\mathrm{CH}_{4}$ production rates of E. huxleyi reported by Scranton (1977) with those of our study. Scranton (1977) reported a production rate of $2 \times 10^{-10} \mathrm{nmol} \mathrm{CH}_{4}$ cell $^{-1} \mathrm{~h}^{-1}$. This value is close to the production rate of $1.6 \times 10^{-10} \mathrm{nmol} \mathrm{CH}_{4}$ cell $^{-1} \mathrm{~h}^{-1}$ in our study. Scranton (1977) concluded from observed $\mathrm{CH}_{4}$ production rates in laboratory experiments that natural populations might be adequate to support the widespread supersaturation of $\mathrm{CH}_{4}$ observed in the open ocean. However, we suggest that the $\mathrm{CH}_{4}$ production of various algae might differ substantially under changing environmental conditions, as already shown for terrestrial plants (Abdulmajeed and 
Qaderi, 2017; Martel and Qaderi, 2017). Moreover, the cellular concentrations of potential precursor compounds such as methylated sulfur compounds might vary greatly between species and cultures. The investigated algal species can reach millimolar intracellular concentrations of DMS and DMSP (Sunda et al., 2002; Liss et al., 1994; Keller, 1989), and even if the conversion rate of methylated sulfur compounds to $\mathrm{CH}_{4}$ in algal cells might be low, they could be sufficient to explain a substantial fraction of the $\mathrm{CH}_{4}$ production rates by marine algae.

\subsection{Implication for the marine environment and algal blooms}

In general, the distribution of chlorophyll has not shown a consistent correlation with $\mathrm{CH}_{4}$ distributions in field studies. There are studies in which no correlation was observed (e.g., Lamontagne et al., 1975; Foster et al., 2006; Watanabe et al., 1995) or a correlation was found within a few depth profiles (Burke et al., 1983; Brooks et al., 1981). Many field measurements in oxygenated surface waters in marine and limnic environments have shown examples of elevated $\mathrm{CH}_{4}$ concentrations spatially related to phytoplankton occurrence (e.g., Conrad and Seifer, 1988; Owens et al., 1991; Oudot et al., 2002; Damm et al., 2008; Grossart, et al., 2011; Weller et al., 2013; Zindler et al., 2013; Tang et al., 2014; Bogard et al., 2014; Rakowski et al., 2015). Taken together these studies suggest that phytoplankton is not the sole source of $\mathrm{CH}_{4}$ in oxygenated surface waters, but importantly, they also suggest that phytoplankton is one of the sources of $\mathrm{CH}_{4}$. We therefore compared the $\mathrm{CH}_{4}$ production rates of our cultures with two field studies for the Pacific Ocean (Weller et al., 2013) and the Baltic Sea (Schmale et al., 2018) to evaluate the potential relevance of algal $\mathrm{CH}_{4}$ production. It was estimated that the gross $\mathrm{CH}_{4}$ production in a southwest Pacific Ocean mesoscale eddy is $40-58 \mathrm{pmol} \mathrm{CH}_{4} \mathrm{~L}^{-1} \mathrm{~d}^{-1}$ (Weller et al., 2013). Using reported phytoplankton cell densities $\left(1.7 \times 10^{8}\right.$ to $2.9 \times 10^{8}$ cells $\mathrm{L}^{-1}$, Weller et al., 2013), we calculated a maximal cellular production of $5.5 \mathrm{ag} \mathrm{CH}_{4}$ cell $^{-1} \mathrm{~d}^{-1}$ for this eddy. The species investigated in this study showed ca. 3-11 times higher cellular production (Table 1). Hence, each of the three haptophyte algae studied here could account for the $\mathrm{CH}_{4}$ production reported by Weller et al. (2013).

Schmale et al. (2018) reported $\mathrm{CH}_{4}$ enrichments that were observed during summer in the upper water column of the Gotland Basin, central Baltic Sea. Furthermore, they found that zooplankton is one but not the only $\mathrm{CH}_{4}$ source in the oxygenated upper waters. While the authors ruled out a major contribution of algae to the observed sub-thermocline $\mathrm{CH}_{4}$ enrichment because of the low sub-thermocline phytoplankton biomass, they considered primary-production-associated $\mathrm{CH}_{4}$ formation to be one likely source in the phytoplanktonrich mixed layer. The average phytoplankton carbon biomass of the mixed layer was approximately $600 \mu \mathrm{g} \mathrm{L}-1$ (averaged from Fig. 9 in Schmale et al., 2018). For the re- ported average net $\mathrm{CH}_{4}$ production rate in the mixed layer $\left(95 \mathrm{pmol} \mathrm{CH}_{4} \mathrm{~L}^{-1} \mathrm{~d}^{-1}\right)$, we calculated that a production rate of $2.5 \mu \mathrm{g} \mathrm{g}^{-1} \mathrm{POC} \mathrm{d}^{-1}$ is required if the $\mathrm{CH}_{4}$ is produced by the algal biomass. This rate would be within the range of $\mathrm{CH}_{4}$ production rates observed in our study. These calculations should be considered as a first rough estimate to assess whether the $\mathrm{CH}_{4}$ production rates of laboratory-grown cultures can significantly contribute to $\mathrm{CH}_{4}$ supersaturation associated with phytoplankton. We did not distinguish between species and did not take into account environmental factors or the complexity of microbiological communities.

Judging from cellular production, the species studied here are of similar importance for oceanic $\mathrm{CH}_{4}$ production in biogeochemical terms. Regarding the highest cellular production, with that of E. huxleyi as $100 \%, P$. globosa produces $27 \%$ and Chrysochromulina sp. $71 \%$ (Table 1). However, several recent studies have emphasized that production potential (PP), as opposed to cellular production, is a biogeochemically meaningful parameter (Gafar et al., 2018; Marra, 2002; Schlüter et al., 2014; Kottmeier et al., 2016). The concept of production potential goes back at least to the first half of the 20th century (Clarke et al., 1946). Briefly, the production potential of substance $X$ is the amount of $X$ which a phytoplankton community or culture produces in a given time. For details, see Sect. 2 and the references above. Cellular production, by contrast, is the rate of production of $X$ of a single cell, and therefore the cellular production is illqualified to express community-level production. We calculated the $\mathrm{CH}_{4}-\mathrm{PP}$ (Sect. 2) for our three species, and when the one of E. huxleyi is considered to be $100 \%, P$. globosa has a $\mathrm{CH}_{4}-\mathrm{PP}$ of $0.9 \%$ and Chrysochromulina sp. $0.8 \%$ (Table 1). In terms of $\mathrm{CH}_{4}$ production in the field, therefore, E. huxleyi outperforms the other two haptophytes by 2 orders of magnitude. It can be concluded that the $\mathrm{CH}_{4}-\mathrm{PP}$ under given environmental conditions is species-specific, and therefore community composition will have an influence on algal sea surface water $\mathrm{CH}_{4}$ production.

It can be hypothesized that changing environmental conditions might drastically affect algal $\mathrm{CH}_{4}$ production, which has to be taken into account when calculating annual averages. The effect of dominant environmental parameters such as light intensity and temperature on algal $\mathrm{CH}_{4}$ production will therefore be the subject matter of future studies.

Data availability. We provide the data in heiDATA, which is an institutional repository for research data of Heidelberg University (https://doi.org/10.11588/data/9N1LSR; Klintzsch and Keppler, 2019).

Supplement. The supplement related to this article is available online at: https://doi.org/10.5194/bg-16-4129-2019-supplement. 
Author contributions. GL, GN, TK, KL, and FK conceived the study and designed the experiments; TK performed the experiments under the supervision of FK and GL; AW helped with the cultivation of algae and measurements; TK, FK, and GL analyzed the data; FK, GL, GN, KL, and TK discussed the results, and GL, TK, and FK wrote the paper.

Competing interests. The authors declare that they have no conflict of interest.

Acknowledgements. We thank Markus Greule, Bernd Knape, and Stefan Rheinberger for conducting analytical measurements and for the technical support that helped to produce this dataset. We acknowledge financial support by the Deutsche Forschungsgemeinschaft within the funding program Open Access Publishing, by the Baden-Württemberg Ministry of Science, Research and the Arts, and by Ruprecht-Karls-Universität Heidelberg.

Financial support. This research has been supported by the Deutsche Forschungsgemeinschaft (grant nos. KE 884/8-2, KE 884/11-1, and KE 884/16-2), the Natural Environment Research Council (grant no. NE/N011708/1), the Baden-Württemberg Ministry of Science, Research and the Arts, and Ruprecht-KarlsUniversität Heidelberg.

Review statement. This paper was edited by Jack Middelburg and reviewed by Mary Scranton and one anonymous referee.

\section{References}

Abdulmajeed, A. M. and Qaderi, M. M.: Intrashoot variation in aerobic methane emissions from pea plants exposed to multiple abiotic stresses, Acta Physiol. Plant., 39, 124, https://doi.org/10.1007/s11738-017-2420-y, 2017.

Althoff, F., Benzing, K., Comba, P., McRoberts, C., Boyd, D. R., Greiner, S., and Keppler, F.: Abiotic methanogenesis from organosulphur compounds under ambient conditions, Nat. Commun., 5, 4205, https://doi.org/10.1038/ncomms5205, 2014.

Angel, R., Matthies, D., and Conrad, R.: Activation of Methanogenesis in Arid Biological Soil Crusts Despite the Presence of Oxygen, Plos One, 6, e20453, https://doi.org/10.1371/journal.pone.0020453, 2011.

Bange, H. W. and Uher, G.: Photochemical production of methane in natural waters: implications for its present and past oceanic source, Chemosphere, 58, 177-183, https://doi.org/10.1016/j.chemosphere.2004.06.022, 2005.

Bange, H. W., Bartell, U., Rapsomanikis, S., and Andreae, M. O.: Methane in the Baltic and North Seas and a reassessment of the marine emissions of methane, Global Biogeochem. Cy., 8, 465480, 1994

Benzing, K., Comba, P., Martin, B., Pokrandt, B., and Keppler, F.: Nonheme Iron-Oxo-Catalyzed Methane Formation from Methyl Thioethers: Scope, Mechanism, and Relevance for Natu- ral Systems, Chemistry, A European Journal, 23, 10465-10472, https://doi.org/10.1002/chem.201701986, 2017.

Bizic-Ionescu, M., Klintzch, T., Ionescu, D., Hindiyeh, M. Y., Guenthel, M., Muro Pastor, A. M., Keppler, F., and Grossart, H.-P.: Widespread formation of methane by Cyanobacteria in aquatic and terrestrial environments, https://doi.org/10.1101/398958, 2018a.

Bižić-Ionescu, M., Ionescu, D., Günthel, M., Tang, K. W., and Grossart, H.-P.: Oxic Methane Cycling: New Evidence for Methane Formation in Oxic Lake Water, in: Biogenesis of Hydrocarbons, edited by: Stams, A. J. M and Souna, D. Z., Springer International Publishing, Basel, 1-22, 2018b.

Bogard, M. J., del Giorgio, P. A., Boutet, L., Chaves, M. C. G., Prairie, Y. T., Merante, A., and Derry, A. M.: Oxic water column methanogenesis as a major component of aquatic $\mathrm{CH}_{4}$ fluxes, Nat. Commun., 5, 5350, https://doi.org/10.1038/ncomms6350, 2014.

Borges, A. V., Speeckaert, G., Champenois, W., Scranton, M. I., and Gypens, N.: Productivity and temperature as drivers of seasonal and spatial variations of dissolved methane in the Southern Bight of the North Sea, Ecosystems, 21, 583-599, 2018.

Boros, M. and Keppler, F.: Production and Signaling of Methane, in: Gasotransmitters, edited by: Wang, R., Royal Society of Chemistry, London, 192-234, https://doi.org/10.1039/9781788013000, 2018

Brooks, J. M., Reid, D. F., and Bernard, B. B.: Methane in the upper water column of the northwestern Gulf of Mexico, J. Geophys. Res.-Ocean., 86, 11029-11040, https://doi.org/10.1029/JC086iC11p11029, 1981.

Brown, C. W. and Yoder, J. A.: Coccolithophorid blooms in the global ocean, J. Geophys. Res.-Ocean., 99, 7467-7482, 1994.

Bruhn, D., Møller, I. M., Mikkelsen, T. N., and Ambus, P.: Terrestrial plant methane production and emission, Physiol. Plantarum, 144, 201-209, 2012.

Burke Jr., R. A., Reid, D. F., Brooks, J. M., and Lavoie, D. M.: Upper water column methane geochemistry in the eastern tropical North Pacific1, Limnol. Oceanogr., 28, 19-32, https://doi.org/10.4319/lo.1983.28.1.0019, 1983.

Clarke, G. L., Edmondson, W. T., and Ricker, W. E.: Dynamics of Production in a Marine Area, Ecol. Monogr., 16, 321-337, https://doi.org/10.2307/1961639, 1946.

Comba, P., Faltermeier, D., Gieger, S., Keppler, F., Schöler, H. F., and Schroll, M.: Iron catalyzed demethylation of acetic acid, J. Coord. Chem., 71, 1704-1714, https://doi.org/10.1080/00958972.2018.1490414, 2018.

Conrad, R. and Seiler, W.: Methane and hydrogen in seawater (Atlantic Ocean), Deep-Sea Res. Pt. A, 35, 1903-1917, https://doi.org/10.1016/0198-0149(88)90116-1, 1988.

Damm, E., Kiene, R. P., Schwarz, J., Falck, E., and Dieckmann, G.: Methane cycling in Arctic shelf water and its relationship with phytoplankton biomass and DMSP, Mar. Chem., 109, 4559, https://doi.org/10.1016/j.marchem.2007.12.003, 2008.

Damm, E., Helmke, E., Thoms, S., Schauer, U., Nöthig, E., Bakker, K., and Kiene, R. P.: Methane production in aerobic oligotrophic surface water in the central Arctic Ocean, Biogeosciences, 7, 1099-1108, https://doi.org/10.5194/bg-7-1099-2010, 2010.

Damm, E., Rudels, B., Schauer, U., Mau, S., and Dieckmann, G.: Methane excess in Arctic surface water-triggered 
by sea ice formation and melting, Sci. Rep., 5, 16179, https://doi.org/10.1038/srep16179, 2015.

de Angelis, M. A. and Lee, C.: Methane production during zooplankton grazing on marine phytoplankton, Limnol. Oceanogr., 39, 1298-1308, 1994.

del Valle, D. A. and Karl, D. M.: Aerobic production of methane from dissolved water-column methylphosphonate and sinking particles in the North Pacific Subtropical Gyre, Aquat. Microb. Ecol., 73, 93-105, 2014.

Denman, K. L., Brasseur, G., Chidthaisong, A., Ciais, P., Cox, P. M., Dickinson, R. E., Hauglustaine, D., Heinze, C., Holland, E., Jacob, D., Lohmann, U., Ramachandran, S., Dias, P. L. d. S., Wofsy, S. C., and Zhang, X.: Couplings between changes in the climate system and biogeochemistry., in: Climate Change 2007: The Physical Science Basis. Contribution of Working Group I to the Fourth Assessment Report of the Intergovernmental Panel on Climate Change, edited by: Solomon, S., Qin, D., Manning, M., Chen, Z., Marquis, M., Averyt, K. B., Tignor, M., and Miller, H. L., Cambridge University Press, Cambridge, United Kingdom and New York, NY, USA, 500-587, 2007.

Donis, D., Flury, S., Stöckli, A., Spangenberg, J. E., Vachon, D., and McGinnis, D. F.: Full-scale evaluation of methane production under oxic conditions in a mesotrophic lake, Nat. Commun., 8, 1661, https://doi.org/10.1038/s41467-017-01648-4, 2017.

Field, C. B., Behrenfeld, M. J., Randerson, J. T., and Falkowski, P.: Primary production of the biosphere: Integrating terrestrial and oceanic components, Science, 281, 237-240, 1998.

Florez-Leiva, L., Damm, E., and Farías, L.: Methane production induced by dimethylsulfide in surface water of an upwelling ecosystem, Prog. Oceanogr., 112, 38-48, 2013.

Forster, G., Upstill-Goddard, R. C., Gist, N., Robinson, C., Uher, G., and Woodward, E. M. S.: Nitrous oxide and methane in the Atlantic Ocean between $50^{\circ} \mathrm{N}$ and $52^{\circ} \mathrm{S}$ : latitudinal distribution and sea-to-air flux, Deep-Sea Res. Pt. II, 56, 964-976, 2009.

Gafar, N. A., Eyre, B. D., and Schulz, K. G.: A conceptual model for projecting coccolithophorid growth, calcification and photosynthetic carbon fixation rates in response to global ocean change, Front. Mar. Sci., 4, 433, https://doi.org/10.3389/fmars.2017.00433, 2018.

Ghyczy, M., Torday, C., Kaszaki, J., Szabo, A., Czobel, M., and Boros, M.: Hypoxia-induced generation of methane in mitochondria and eukaryotic cells - An alternative approach to methanogenesis, Cell. Physiol. Biochem., 21, 251-258, 2008.

Grossart, H.-P., Frindte, K., Dziallas, C., Eckert, W., and Tang, K. W.: Microbial methane production in oxygenated water column of an oligotrophic lake, P. Natl. Acad. Sci. USA, 108, 1965719661, https://doi.org/10.1073/pnas.1110716108, 2011.

Guillard, R. R. and Ryther, J. H.: Studies of marine planktonic diatoms: I. Cyclotella nana Hustedt, and Detonula confervacea (Cleve) Gran, Can. J. Microbiol., 8, 229-239, 1962.

Herscu-Kluska, R., Masarwa, A., Saphier, M., Cohen, H., and Meyerstein, D.: Mechanism of the reaction of radicals with peroxides and dimethyl sulfoxide in aqueous solution, Chemistry - A European Journal, 14, 5880-5889, 2008.

Hohenberger, J., Ray, K., and Meyer, K.: The biology and chemistry of high-valent iron-oxo and iron-nitrido complexes, Nat. Commun., 3, 720, https://doi.org/10.1038/ncomms1718, 2012.

Holligan, P. M., Fernández, E., Aiken, J., Balch, W. M., Boyd, P., Burkill, P. H., Finch, M., Groom, S. B., Malin, G., and Muller,
K.: A biogeochemical study of the coccolithophore, Emiliania huxleyi, in the North Atlantic, Global Biogeochem. Cy., 7, 879900, 1993.

Karl, D. M. and Tilbrook, B. D.: Production and transport of methane in oceanic particulate organic matter, Nature, 368, 732734, 1994.

Karl, D. M., Beversdorf, L., Bjorkman, K. M., Church, M. J., Martinez, A., and DeLong, E. F.: Aerobic production of methane in the sea, Nat. Geosci., 1, 473-478, https://doi.org/10.1038/ngeo234, 2008.

Keeling, C. D.: The concentration and isotopic abundances of atmospheric carbon dioxide in rural areas, Geochim. Cosmochim. Ac., 13, 322-334, https://doi.org/10.1016/0016-7037(58)900334, 1958.

Keller, M. D.: Dimethyl sulfide production and marine phytoplankton: the importance of species composition and cell size, Biol. Oceanogr., 6, 375-382, 1989.

Keppler, F., Hamilton, J. T. G., Brass, M., and Rockmann, T.: Methane emissions from terrestrial plants under aerobic conditions, Nature, 439, 187-191, 2006.

Keppler, F., Boros, M., Frankenberg, C., Lelieveld, J., McLeod, A., Pirttila, A. M., Rockmann, T., and Schnitzler, J. P.: Methane formation in aerobic environments, Environ. Chem., 6, 459-465, https://doi.org/10.1071/en09137, 2009.

Keppler, F., Schiller, A., Ehehalt, R., Greule, M., Hartmann, J., and Polag, D.: Stable isotope and high precision concentration measurements confirm that all humans produce and exhale methane, J. Breath Res., 10, 016003, https://doi.org/10.1088/17527155/10/1/016003, 2016.

Kirschke, S., Bousquet, P., Ciais, P., Saunois, M., Canadell, J. G., Dlugokencky, E. J., Bergamaschi, P., Bergmann, D., Blake, D. R., Bruhwiler, L., Cameron-Smith, P., Castaldi, S., Chevallier, F., Feng, L., Fraser, A., Heimann, M., Hodson, E. L., Houweling, S., Josse, B., Fraser, P. J., Krummel, P. B., Lamarque, J. F., Langenfelds, R. L., Le Quere, C., Naik, V., O’Doherty, S., Palmer, P. I., Pison, I., Plummer, D., Poulter, B., Prinn, R. G., Rigby, M., Ringeval, B., Santini, M., Schmidt, M., Shindell, D. T., Simpson, I. J., Spahni, R., Steele, L. P., Strode, S. A., Sudo, K., Szopa, S., van der Werf, G. R., Voulgarakis, A., van Weele, M., Weiss, R. F., Williams, J. E., and Zeng, G.: Three decades of global methane sources and sinks, Nat. Geosci., 6, 813-823, https://doi.org/10.1038/ngeo1955, 2013.

Klintzsch, T. and Keppler, F.: Methane production by three widespread marine phytoplankton species: release rates, precursor compounds, and potential relevance for the environment, https://doi.org/10.11588/data/9N1LSR, heiDATA, V1, UNF:6:dxf+QSeRKu9v6uPyAUhX8Q==[fileUNF], 2019.

Kottmeier, D. M., Rokitta, S. D., and Rost, B.: $\mathrm{H}^{+}$-driven increase in $\mathrm{CO}_{2}$ uptake and decrease in uptake explain coccolithophores' acclimation responses to ocean acidification, Limnol. Oceanogr., 61, 2045-2057, https://doi.org/10.1002/lno.10352, 2016.

Lamontagne, R. A., Smith, W. D., and Swinnerton, J. W.: $\mathrm{C}_{1}-\mathrm{C}_{3}$ Hydrocarbons and Chlorophyll $a$ Concentrations in the Equatorial Pacific Ocean, in: Analytical Methods in Oceanography, Adv. Chem., 147, Am. Chem. Soc., 147, 163-171, 1975.

Langer, G., Nehrke, G., Probert, I., Ly, J., and Ziveri, P.: Strain-specific responses of Emiliania huxleyi to changing seawater carbonate chemistry, Biogeosciences, 6, 2637-2646, https://doi.org/10.5194/bg-6-2637-2009, 2009. 
Langer, G., Oetjen, K., and Brenneis, T.: Calcification of Calcidiscus leptoporus under nitrogen and phosphorus limitation, J. Exp. Mar. Biol. Ecol., 413, 131-137, 2012.

Langer, G., Oetjen, K., and Brenneis, T.: Coccolithophores do not increase particulate carbon production under nutrient limitation: A case study using Emiliania huxleyi (PML B92/11), J. Exp. Mar. Biol. Ecol., 443, 155-161, 2013.

Laukenmann, S., Polag, D., Heuwinkel, H., Greule, M., Gronauer, A., Lelieveld, J., and Keppler, F.: Identification of methanogenic pathways in anaerobic digesters using stable carbon isotopes, Eng. Life Sci., 10, 509-514, https://doi.org/10.1002/elsc.201000074, 2010.

Lelieveld, J., Crutzen, P. J., and Dentener, F. J.: Changing concentration, lifetime and climate forcing of atmospheric methane, Tellus B, 50, 128-150, 1998.

Lenhart, K., Bunge, M., Rathering, S., Neu, T., Schüttman, I., Greule, M., Kammann, C., Schnell, S., Müller, C., Zorn, H., and Keppler, F.: Evidence for methane production by saprotrophic fungi, Nat. Commun., 3, 1046, https://doi.org/10.1038/ncomms2049, 2012.

Lenhart, K., Althoff, F., Greule, M., and Keppler, F.: Technical Note: Methionine, a precursor of methane in living plants, Biogeosciences, 12, 1907-1914, https://doi.org/10.5194/bg-121907-2015, 2015a.

Lenhart, K., Weber, B., Elbert, W., Steinkamp, J., Clough, T., Crutzen, P., Pöschl, U., and Keppler, F.: Nitrous oxide and methane emissions from cryptogamic covers, Glob. Change Biol., 21, 3889-3900, https://doi.org/10.1111/gcb.12995, 2015b.

Lenhart, K., Klintzsch, T., Langer, G., Nehrke, G., Bunge, M., Schnell, S., and Keppler, F.: Evidence for methane production by the marine algae Emiliania huxleyi, Biogeosciences, 13, 3163 3174, https://doi.org/10.5194/bg-13-3163-2016, 2016.

Liss, P., Malin, G., Turner, S., and Holligan, P.: Dimethyl sulphide and Phaeocystis: a review, J. Mar. Syst., 5, 41-53, 1994.

Marra, J.: Approaches to the Measurement of Plankton Production, in: Phytoplankton Productivity and Carbon Assimilation in Marine and Freshwater Ecoystems, edited by: Williams, P. J., Thomas, D. R., and Reynolds, C. S., London, Blackwell, 222264, 2002

Martel, A. B. and Qaderi, M. M.: Light quality and quantity regulate aerobic methane emissions from plants, Physiol. Plantarum, 159, 313-328, 2017.

Matrai, P. A. and Keller, M. D.: Dimethylsulfide in a large-scale coccolithophore bloom in the Gulf of Maine, Cont. Shelf Res., 13, 831-843, 1993.

Menden-Deuer, S. and Lessard, E. J.: Carbon to volume relationships for dinoflagellates, diatoms, and other protist plankton, Limnol. Oceanogr., 45, 569-579, 2000.

Metcalf, W. W., Griffin, B. M., Cicchillo, R. M., Gao, J. T., Janga, S. C., Cooke, H. A., Circello, B. T., Evans, B. S., MartensHabbena, W., Stahl, D. A., and van der Donk, W. A.: Synthesis of Methylphosphonic Acid by Marine Microbes: A Source for Methane in the Aerobic Ocean, Science, 337, 1104-1107, https://doi.org/10.1126/science.1219875, 2012.

Olenina, I., Hajdu, S., Edler, L., Andersson, A., Wasmund, N., Busch, S., Göbel, J., Gromisz, S., Huseby, S., Huttunen, M., Jaanus, A., Kokkonen, P., Ledaine, I., and Niemkiewicz, E.: Biovolumes and size-classes of phytoplankton in the Baltic Sea HELCOM Balt, Sea Environ. Proc. No. 106, 144 pp., 2006.
Oremland, R. S.: Methanogenic activity in plankton samples and fish intestines - mechanism for insitu methanogenesis in oceanic surface waters, Limnol. Oceanogr., 24, 1136-1141, 1979.

Oudot, C., Jean-Baptiste, P., Fourré, E., Mormiche, C., Guevel, M., Ternon, J.-F., and Le Corre, P.: Transatlantic equatorial distribution of nitrous oxide and methane, Deep-Sea Res. Pt. I, 49, 1175 1193, https://doi.org/10.1016/S0967-0637(02)00019-5, 2002.

Owens, N. J. P., Law, C. S., Mantoura, R. F. C., Burkill, P. H., and Llewellyn, C. A.: Methane flux to the atmosphere from the Arabian Sea, Nature, 354, 293-296, https://doi.org/10.1038/354293a0, 1991.

Pataki, D. E., Ehleringer, J. R., Flanagan, L. B., Yakir, D., Bowling, D. R., Still, C. J., Buchmann, N., Kaplan, J. O., and Berry, J. A.: The application and interpretation of Keeling plots in terrestrial carbon cycle research, Global Biogeochem. Cy., 17, 1022, https://doi.org/10.1029/2001GB001850, 2003.

Paul, D., Skrzypek, G., and Fórizs, I.: Normalization of measured stable isotopic compositions to isotope reference scales - a review, Rapid Commun. Mass Sp., 21, 3006-3014, https://doi.org/10.1002/rcm.3185, 2007.

Rakowski, C., Magen, C., Bosman, S., Gillies, L., Rogers, K., Chanton, J., and Mason, O. U.: Methane and microbial dynamics in the Gulf of Mexico water column, Front. Mar. Sci., 2, 69, https://doi.org/10.3389/fmars.2015.00069, 2015.

Reeburgh, W. S.: Oceanic methane biogeochemistry, Chem. Rev., 107, 486-513, https://doi.org/10.1021/cr050362v, 2007.

Repeta, D. J., Ferrón, S., Sosa, O. A., Johnson, C. G., Repeta, L. D., Acker, M., DeLong, E. F., and Karl, D. M.: Marine methane paradox explained by bacterial degradation of dissolved organic matter, Nat. Geosci., 9, 884-887, 2016.

Saunois, M., Bousquet, P., Poulter, B., Peregon, A., Ciais, P., Canadell, J. G., Dlugokencky, E. J., Etiope, G., Bastviken, D., and Houweling, S.: The global methane budget 2000-2012, Earth Syst. Sci. Data, 8, 697-751, 2016.

Schindelin, J., Arganda-Carreras, I., Frise, E., Kaynig, V., Longair, M., Pietzsch, T., Preibisch, S., Rueden, C., Saalfeld, S., and Schmid, B.: Fiji: an open-source platform for biological-image analysis, Nat. Methods, 9, 676, https://doi.org/10.1038/nmeth.2019, 2012.

Schlüter, L., Lohbeck, K. T., Gutowska, M. A., Gröger, J. P., Riebesell, U., and Reusch, T. B. H.: Adaptation of a globally important coccolithophore to ocean warming and acidification, Nat. Clim. Change, 4, 1024, https://doi.org/10.1038/nclimate2379, 2014.

Schmale, O., Wäge, J., Mohrholz, V., Wasmund, N., Gräwe, U., Rehder, G., Labrenz, M., and Loick-Wilde, N.: The contribution of zooplankton to methane supersaturation in the oxygenated upper waters of the central Baltic Sea, Limnol. Oceanogr., 63, 412-430, 2018.

Schoemann, V., Becquevort, S., Stefels, J., Rousseau, V., and Lancelot, C.: Phaeocystis blooms in the global ocean and their controlling mechanisms: a review, J. Sea Res., 53, 43-66, 2005.

Scranton, M. I.: The marine geochemistry of methane, Ph.D., Massachusetts Institute of Technology and Woods Hole Oceanographic Institution, Massachusetts, USA, 251 pp., 1977.

Scranton, M. I. and Brewer, P. G.: Occurrence of methane in the near-surface waters of the western subtropical North-Atlantic, Deep-Sea Res., 24, 127-138, https://doi.org/10.1016/01466291(77)90548-3, 1977. 
Scranton, M. I. and Farrington, J. W.: Methane production in the waters off Walvis Bay, J. Geophys. Res., 82, 4947-4953, https://doi.org/10.1029/JC082i031p04947, 1977.

Stawiarski, B., Otto, S., Thiel, V., Gräwe, U., Loick-Wilde, N., Wittenborn, A. K., Schloemer, S., Wäge, J., Rehder, G., Labrenz, M., Wasmund, N., and Schmale, O.: Controls on zooplankton methane production in the central Baltic Sea, Biogeosciences, 16, 1-16, https://doi.org/10.5194/bg-16-1-2019, 2019.

Stefels, J., Steinke, M., Turner, S., Malin, G., and Belviso, S.: Environmental constraints on the production and removal of the climatically active gas dimethylsulphide (DMS) and implications for ecosystem modelling, Biogeochemistry, 83, 245-275, https://doi.org/10.1007/s10533-007-9091-5, 2007.

Sunda, W., Kieber, D. J., Kiene, R. P., and Huntsman, S.: An antioxidant function for DMSP and DMS in marine algae, Nature, 418, 317-320, https://doi.org/10.1038/nature00851, 2002.

Tang, K. W., McGinnis, D. F., Frindte, K., Brüchert, V., and Grossart, H.-P.: Paradox reconsidered: Methane oversaturation in well-oxygenated lake waters, Limnol. Oceanogr., 59, 275-284, 2014.

Thomsen, H. A. Buck, K.R. and Chavez F.P.: Haptophytes as components of marine phytoplankton, in: The Haptophyte Algae, edited by: Green, J. C. and Leadbeater, B. S. C., Clarendon Press, Oxford, 187-208, 1994
Watanabe, S., Higashitani, N., Tsurushima, N., and Tsunogai, S.: Methane in the western North Pacific, J. Oceanogr., 51, 39-60, https://doi.org/10.1007/bf02235935, 1995.

Weller, D. I., Law, C. S., Marriner, A., Nodder, S. D., Chang, F. H., Stephens, J. A., Wilhelm, S. W., Boyd, P. W., and Sutton, P. J. H.: Temporal variation of dissolved methane in a subtropical mesoscale eddy during a phytoplankton bloom in the southwest Pacific Ocean, Prog. Oceanogr., 116, 193-206, https://doi.org/10.1016/j.pocean.2013.07.008, 2013.

Wiesenburg, D. A. and Guinasso, N. L.: Equilibrium solubilities of methane, carbon monoxide, and hydrogen in water and sea water, J. Chem. Eng. Data, 24, 356-360, https://doi.org/10.1021/je60083a006, 1979.

Zhang, Y. and Xie, H.: Photomineralization and photomethanification of dissolved organic matter in Saguenay River surface water, Biogeosciences, 12, 6823-6836, https://doi.org/10.5194/bg-126823-2015, 2015.

Zindler, C., Bracher, A., Marandino, C. A., Taylor, B., Torrecilla, E., Kock, A., and Bange, H. W.: Sulphur compounds, methane, and phytoplankton: interactions along a north-south transit in the western Pacific Ocean, Biogeosciences, 10, 3297-3311, https://doi.org/10.5194/bg-10-3297-2013, 2013. 